\title{
Enthalpy of formation of ye'elimite and ternesite
}

\author{
Solon Skalamprinos ${ }^{1}$ (1) $\cdot$ Isabel Galan $^{1,2} \cdot$ Theodore Hanein $^{3} \cdot$ Fredrik Glasser $^{1}$
}

Received: 15 July 2017/ Accepted: 26 September 2017/Published online: 17 October 2017

(c) The Author(s) 2017. This article is an open access publication

\begin{abstract}
Calcium sulfoaluminate clinkers containing ye'elimite $\left(\mathrm{Ca}_{4} \mathrm{Al}_{6} \mathrm{O}_{12}\left(\mathrm{SO}_{4}\right)\right)$ and ternesite $\left(\mathrm{Ca}_{5}\left(\mathrm{SiO}_{4}\right)_{2}\right.$ $\mathrm{SO}_{4}$ ) are being widely investigated as components of calcium sulfoaluminate cement clinkers. These may become low energy replacements for Portland cement. Conditional thermodynamic data for ye'elimite and ternesite (enthalpy of formation) have been determined experimentally using a combination of techniques: isothermal conduction calorimetry, X-ray powder diffraction and thermogravimetric analysis. The enthalpies of formation of ye'elimite and ternesite at $25{ }^{\circ} \mathrm{C}$ were determined to be -8523 and $-5993 \mathrm{~kJ} \mathrm{~mol}^{-1}$, respectively.
\end{abstract}

Keywords Ye'elimite - Ternesite - Enthalpy of formation · Calorimetry $\cdot$ Thermogravimetric analysis $\cdot$ Calcium sulfoaluminate cement

\section{Introduction}

Calcium sulfoaluminate (C $\bar{S} A)$ cements, commercially developed in China in the 1970's, are widely regarded as one of the new generation of "eco-friendly" cements and are currently undergoing optimisation. C $\overline{S A}$ cements can compete with the dominance of Portland cement (PC)

Solon Skalamprinos

s.skalamprinos@outlook.com

1 Department of Chemistry, University of Aberdeen, Aberdeen AB24 3UE, UK

2 Institute of Applied Geosciences, Graz University of Technology, Rechbauerstrasse 12, 8010 Graz, Austria

3 Department of Materials Science and Engineering, University of Sheffield, Sheffield S1 3JD, UK because $\mathrm{C} \overline{\mathrm{S}} \mathrm{A}$ formulations reduce $\mathrm{CO}_{2}$ emissions by approximately 30 mass \% [1-4]. CSA cements are typically made by clinkering at high-temperature mixtures of limestone, bauxite, clay, and calcium sulphate, forming clinkers consisting primarily of ye'elimite $\left(\mathrm{C}_{4} \mathrm{~A}_{3} \overline{\mathrm{S}}\right)^{1}$ and belite $\left(\mathrm{C}_{2} \mathrm{~S}\right)$. Compared with $\mathrm{PC}, \mathrm{CS} A$ requires less calcium per $\mathrm{kg}$ clinker; therefore, less limestone needs to be decarbonated, resulting in a lower carbon footprint. C $\bar{S} A$ clinker is also produced at $1250-1300{ }^{\circ} \mathrm{C}$; this is approximately $200{ }^{\circ} \mathrm{C}$ less than that of PC clinker manufacture, leading to a reduction in both the quality and quantity of required fuel. The embodied $\mathrm{CO}_{2}$ is also reduced due to the friability of $C \bar{S} A$ clinkers, reducing the energy requirements for grinding [3, 5-10].

In the search to develop new cements, empirical methods have traditionally been used to optimise compositions. Classical approaches, such as thermodynamics, have not been much used partly because thermodynamic data are sparse, of uncertain reliability, or absent. Nevertheless, we have found simple thermodynamic approaches to provide a valuable tool to optimise compositions and facilitate partial substitution of hydrocarbon fuels by sulphur combustion [11].

The thermodynamic database assembled by Wagman et al. [12] evaluates different data, and we follow these selection criteria. Wagman et al. compiled thermodynamic properties, including standard enthalpy of formation, standard Gibbs free energy, entropy and heat capacity at constant pressure, of inorganic and organic substances, including various cement phases. The selection criteria of conditional thermodynamic values included how the thermodynamic values were measured and the

\footnotetext{
${ }^{1}$ Cement shorthand notations used throughout the text include: $\mathrm{C}$ : $\mathrm{CaO}, \mathrm{A}: \mathrm{Al}_{2} \mathrm{O}_{3}, \overline{\mathrm{S}}: \mathrm{SO}_{3}, \mathrm{H}: \mathrm{H}_{2} \mathrm{O}, \mathrm{S}: \mathrm{SiO}_{2}, \mathrm{~F}: \mathrm{Fe}_{2} \mathrm{O}_{3}$.
} 
reliability of the data: weighting factors included the probable accuracy of the experimental method, acceptable characterization of the substances, chemical purity and finally, the consistency of the results. Enthalpy data collated by Wagman et al., were determined using four approaches: (i) from calorimetrically measured enthalpies of reaction, fusion, vaporisation, sublimation, transition, solution and dilution; (ii) indirectly, from temperature variation of equilibrium constants; (iii) from spectroscopically determined dissociation energies and (iv) calculations from Gibbs energies and entropies.

Our work, described in [11, 13-17], has identified major areas of deficiency of thermodynamic data for the enthalpy of formation of both ye'elimite and ternesite. Scientists seem to have moved away from the experimental derivation of thermodynamic data, and the equipment previously used has become scarce. Drop calorimeters are usually the preferred choice to measure heats of formation of inorganic compounds, but such equipment was not available to us. However, our ability to measure the heat of hydration (heat of reaction) with calorimetry drove us to determine these values using a series of experimental procedures that combine several techniques: isothermal conduction calorimetry, X-ray powder diffraction (Rietveld analysis and the G-factor method) and thermogravimetric analysis (TGA).

Data for this work were collected at $25{ }^{\circ} \mathrm{C}$. Therefore, the immediate application can be achieved by incorporating the data in software e.g. Gibbs Energy Minimisation Selektor (GEMS) [18, 19], used to model cement hydration processes, at or near ambient temperature. The data produced here will also have application when carrying out high-temperature thermodynamic calculations once their temperature-dependant heat capacities become available.

\section{Ye'elimite}

CS A clinkers have relatively high exothermic heats of hydration mainly due to the hydration of ye'elimite. Several authors have studied its hydration: it reacts with water at $25{ }^{\circ} \mathrm{C}$ forming calcium monosulfoaluminate hydrate, "monosulphate (AFm)", and aluminium hydroxide, but in the presence of both water and a stoichiometric excess of calcium sulphate, it forms ettringite (AFt) and aluminium hydroxide, Eqs. 1 and 2.

$$
\begin{aligned}
& \mathrm{C}_{4} \mathrm{~A}_{3} \overline{\mathrm{S}}+18 \mathrm{H} \rightarrow \mathrm{C}_{3} \mathrm{~A} \cdot \mathrm{C} \overline{\mathrm{S}} \cdot 12 \mathrm{H}+2 \mathrm{AH}_{3} \\
& \mathrm{C}_{4} \mathrm{~A}_{3} \overline{\mathrm{S}}+2 \mathrm{C} \overline{\mathrm{S}} \mathrm{H}_{2}+34 \mathrm{H} \rightarrow \mathrm{C}_{3} \mathrm{~A} \cdot 3 \mathrm{C} \overline{\mathrm{S}} \cdot 32 \mathrm{H}+2 \mathrm{AH}_{3}
\end{aligned}
$$

Cuesta et al. [20] investigated the hydration mechanism of the two polymorphs of synthetic ye'elimite, and its solid solution $\left(\mathrm{Ca}_{3.8} \mathrm{Na}_{0.2} \mathrm{Al}_{5.6} \mathrm{Fe}_{0.2} \mathrm{Si}_{0.2} \mathrm{O}_{12} \mathrm{SO}_{4}\right)$ after 2 and 7 days of hydration; in the absence of additional sulphate, the hydration products consisted of a mixture of AFm and $\mathrm{AFt}^{2}$, while in the presence of calcium sulphate, $\mathrm{AFt}$ developed and AFm was absent at late ages. The heat release of stoichiometric and solid-solution ye'elimite was found to

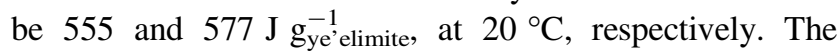
hydration of iron-containing ye'elimite $\left(\mathrm{C}_{4} \mathrm{~A}_{2.7} \mathrm{~F}_{0.3} \overline{\mathrm{S}}\right.$-cubic $)$ and pure ye'elimite (orthorhombic) with and without gypsum was studied by Jansen et al. [21], obtaining minor differences (cubic polymorph showed approx. 2 mass $\%$ less consumption) the first $20 \mathrm{~h}$ of hydration, where orthorhombic ye'elimite heat release was $\approx 515 \mathrm{~J} \mathrm{~g}_{\text {ye' }}^{-1}$ elimite, and cubic ye' elimite $\approx 469 \mathrm{~J} \mathrm{~g}_{\text {ye' }}^{-1}$ limite at $23{ }^{\circ} \mathrm{C}$.

Costa et al. [22] gave thermodynamic values for ye'elimite obtained from solution calorimetry. The heat of formation of ye'elimite was calculated from the data provided by Costa et al. (using: $4 \times \mathrm{CaO}+3 \times \mathrm{Al}_{2} \mathrm{O}_{3}+$ $\mathrm{SO}_{3}$ ) and found to be $-8406 \mathrm{~kJ} \mathrm{~mol}^{-1}$ at $25{ }^{\circ} \mathrm{C}$. Ayed et al. [23] calculated the enthalpy of formation of ye'elimite using a high-temperature conduction microcalorimeter. The synthesis of ye'elimite carried out by using both reagent grade and industrial grade raw materials; no significant differences between the two sets of reactants were observed. At $1300{ }^{\circ} \mathrm{C}$ the enthalpy of formation was found to be endothermic, $6388 \mathrm{~kJ} \mathrm{~mol}^{-1}$ (when using calcium carbonate, alumina and gypsum as raw materials). Sharp et al. [8] calculated the energy requirements $\left(\Delta_{\mathrm{r}} \mathrm{H}\right)$ for ye'elimite formation using standard thermochemical data: $\Delta_{\mathrm{r}} \mathrm{H} \approx 488 \mathrm{~kJ} \mathrm{~mol}^{-1}$. The standard $25{ }^{\circ} \mathrm{C}$ enthalpy of formation of ye'elimite can then be determined by adding the energy requirement to the sum of the enthalpies of the compounds involved, as suggested by Sharp et al. $\left[\left(3 \times \mathrm{CaCO}_{3}+3 \times \mathrm{Al}_{2} \mathrm{O}_{3}+\mathrm{CaSO}_{4}\right)-\right.$ $\left(3 \times \mathrm{CO}_{2}\right)$ ]: the enthalpy value thus obtained is $-8901 \mathrm{~kJ} \mathrm{~mol}^{-1}$ (enthalpy values needed for this calculation were taken from Wagman et al. [12]). By adding the energy requirement of ye'elimite to the enthalpy value, the result is $\approx-8413 \mathrm{~kJ} \mathrm{~mol}^{-1}$. When we repeat a similar generic calculation by adding the enthalpies involved in the synthesis of ye'elimite but replacing $\mathrm{CaCO}_{3}$ by $\mathrm{CaO}$ : $3 \times \mathrm{CaO}+3 \times \mathrm{Al}_{2} \mathrm{O}_{3}+\mathrm{CaSO}_{4}$, the result is $-8366 \mathrm{~kJ} \mathrm{~mol}^{-1}$ (enthalpy values for this calculation were also taken from [12]). Wang et al. [24] reported several methods of calculating the enthalpy of formation and concluded that Wen's method [25] was the most appropriate; it sums the heat of formation of individual

\footnotetext{
$\overline{2}$ AFm and AFt refer to families of hydrated calcium aluminates with a layered and framework structure respectively, where hydroxide ions may be replaced by sulfate or carbonate. The $\mathrm{m}$ and $\mathrm{t}$ in the names indicate that the respective crystal structures allow for singular (mono) or tri-substitution of hydroxide ions. Also, ferric iron (shorthand, F) may partially replace alumina in the structure, hence the designation AFm and AFt. The mineral form of AFt is ettringite and the two terms are used interchangeably throughout this article.
} 
oxide components and the heat of reaction evolved in the algebraic combination of the component oxides. The enthalpy of formation of ye'elimite using Wen's method was $-8393 \mathrm{~kJ} \mathrm{~mol}^{-1}$. Finally, Hanein et al. [26] calculated the enthalpy of formation of ye'elimite at selected high temperatures, using the Clausius-Clapeyron relation, by deriving data from vapour pressure measurements at high temperatures [27], between 1290 and $1675 \mathrm{~K}$, obtaining $-7807 \mathrm{~kJ} \mathrm{~mol}^{-1}$ at $1523 \mathrm{~K}\left(1250{ }^{\circ} \mathrm{C}\right)$.

The reports that calculated the enthalpy of formation of ye'elimite at $25^{\circ} \mathrm{C}$ unfortunately do not distinguish between the polymorphism of ye'elimite (cubic and orthorhombic), and therefore the solid is incompletely defined. Reports that calculated the enthalpy of formation at high temperature are, however, almost certainly attributed to cubic ye'elimite.

\section{Ternesite}

Several authors considered ternesite as a "poorly hydraulic phase" [28-31] except under autoclave temperatures [32]. The characterisation of ternesite as a "poorly hydraulic phase" and therefore its supposed insignificant contribution to the cementing potential, possibly explain why it has received little further investigation and hence the paucity of thermodynamic values. However, more recent reports show ternesite to have promising hydration properties [33-37], so it remains of interest. A generic calculation of the enthalpy of ternesite was done by adding the oxides involved: $4 \times \mathrm{CaO}+2 \times \mathrm{SiO}_{2}+\mathrm{CaSO}_{4}, \quad$ giving $-5696 \mathrm{~kJ} \mathrm{~mol}^{-1}$ : enthalpy values were taken from [12]. Recent, high-temperature thermodynamic data were theoretically derived from vapour pressure measurements [27] by Hanein et al. [15]; the enthalpy of ternesite formation was calculated to be $-5673 \mathrm{~kJ} \mathrm{~mol}^{-1}$ at $1448 \mathrm{~K}$ $\left(1175^{\circ} \mathrm{C}\right)$.

\section{Methods, materials and calculations}

\section{Methods}

Ye'elimite and ternesite phase purity was determined using a PANanalytical Empyrean diffractometer (XRD) in the Bragg-Brentano geometry operating at $45 \mathrm{kV}$ and $40 \mathrm{~mA}$, equipped with a $\mathrm{Cu} \mathrm{K} \alpha^{1}$ X-ray source $(1.5406 \AA$ ), a Ge monochromator and a PIXcel1D detector. The X-ray pattern was measured from $5^{\circ}$ to $70^{\circ} 2 \theta$ with a step size of $0.0132^{\circ}$ and time per step $350.625 \mathrm{~s}$. The stage was set to rotate at a rate of one revolution per $4 \mathrm{~s}$, to improve statistics. The Rietveld refinements [38] were carried out using the GSAS software and the peaks were fitted using a Linear Interpolation function with asymmetry correction and an automatic background fitting [39-41]. The relevant crystal files were sourced from the ICSD database (see Table 1).

Each of three ye'elimite batches (see section "Ye'elimite") was divided into three subsamples, and early-age hydration was followed using an isothermal conduction calorimeter, Calmetrix I-CAL 4000. Sample materials (water, powder sample and mixing spoon) were placed in the calorimeter $24 \mathrm{~h}$ prior testing to allow thermal equilibration. Results were evaluated to verify the repeatability of the instrument: when the difference between measurements was below $3 \%$, results were considered acceptable. All 9 samples were mixed for $20 \mathrm{~s}$ before placing them in the calorimeter. The amounts of ye'elimite, gypsum and water are shown in Table 2. For samples (y) and (yg), double the amount of the theoretical water needed was used to ensure sufficient water was present to reach a high degree of hydration [53]; for samples $\left(\mathrm{y}^{1} / 2 \mathrm{~g}\right)$, the theoretical amount of water was used according to Eq. 2.

For ternesite, the same procedure was followed as with ye'elimite to measure the heat of hydration, with external mixing of $8 \mathrm{~g}$ of solids and $4 \mathrm{~g}$ of water. The water-to-solid ratio of 0.5 was chosen to be approximately double the theoretical amount needed (see Eq. 8) to promote hydration at early ages [53]. The water/solid ratio also allowed for an easier mixing of the samples.

The heat release from early-age hydration was monitored for $72 \mathrm{~h}$ at $25{ }^{\circ} \mathrm{C}$. Prior to measurements, the calorimeter was calibrated to check its drift. To minimise errors, the calorimeter was operated in an isolated room (away from influential factors such as: heating/cooling systems, wind, direct sunlight and vibrations) at $22{ }^{\circ} \mathrm{C}$. The reference mass was also adjusted to match sample heat capacity [53]. After $72 \mathrm{~h}$ inside the calorimeter, the samples were taken out and immediately dried using solvent exchange: about $20 \mathrm{~g}$ of acetone was added to $\approx 5 \mathrm{~g}$ of sample and gently ground to a powder. Once homogenised, more acetone, up to $200 \mathrm{~g}$, was added to displace residual water and left for 5-10 min. The excess acetone was poured out and the sample was left to dry on a filter paper (to increase its surface area) before drying at $30^{\circ} \mathrm{C}$ for approximately $3 \mathrm{~h}$ [54]. The samples were then further disaggregated using a mortar and a pestle to pass a $75 \mu \mathrm{m}$ sieve.

$\mathrm{X}$-ray diffraction (XRD) and thermogravimetric (TG) data were collected. Ye'elimite and ternesite hydrated samples were scanned with the same XRD parameters as described previously. For ye'elimite samples, a manual background fitting along with a Pseudo-Voigt 3 (FJC Asymmetry) function was used: data were analysed using PANalytical High Score Plus software. For ternesite samples, GSAS software was used [39], with a shifted 
Table 1 ICSD codes of all phases involved with the Rietveld analysis

\begin{tabular}{|c|c|c|}
\hline Phase & Formula & $\begin{array}{l}\text { ICSD } \\
\text { code }\end{array}$ \\
\hline Ettringite [42] & $6 \mathrm{CaO} \cdot \mathrm{Al}_{2} \mathrm{O}_{3} \cdot 3 \mathrm{SO}_{3} \cdot 32 \mathrm{H}_{2} \mathrm{O}$ & 155395 \\
\hline Kuzelite [43] & $4 \mathrm{CaO} \cdot \mathrm{Al}_{2} \mathrm{O}_{3} \cdot \mathrm{SO}_{3} \cdot 12 \mathrm{H}_{2} \mathrm{O}$ & 100138 \\
\hline $\begin{array}{l}\text { Ye'elimite (orthorhombic) } \\
\text { [44] }\end{array}$ & $\mathrm{Ca}_{4} \mathrm{Al}_{6} \mathrm{O}_{12}\left(\mathrm{SO}_{4}\right)$ & 80361 \\
\hline Ye'elimite (cubic) [45] & $\mathrm{Ca}_{4} \mathrm{Al}_{6} \mathrm{O}_{12}\left(\mathrm{SO}_{4}\right)$ & 9560 \\
\hline Gypsum [46] & $\mathrm{CaSO}_{4} \cdot 2 \mathrm{H}_{2} \mathrm{O}$ & 2057 \\
\hline Calcium aluminate [47] & $\mathrm{CaAl}_{2} \mathrm{O}_{4}$ & 260 \\
\hline Aluminium oxide [48] & $\mathrm{Al}_{2} \mathrm{O}_{3}$ & 51687 \\
\hline Ternesite [49] & $\mathrm{Ca}_{5}\left(\mathrm{SiO}_{4}\right)_{2} \mathrm{SO}_{4}$ & 85123 \\
\hline Portlandite [50] & $\mathrm{Ca}(\mathrm{OH})_{2}$ & 202228 \\
\hline$\beta$-Belite [51] & $\mathrm{Ca}_{2} \mathrm{SiO}_{4}$ & 81096 \\
\hline$\gamma$-Belite [51] & $\mathrm{Ca}_{2} \mathrm{SiO}_{4}$ & 81095 \\
\hline Anhydrite [52] & $\mathrm{CaSO}_{4}$ & 16382 \\
\hline
\end{tabular}

Table 2 Amount of ye'elimite, gypsum and water incorporated for the heat evolution measurements

\begin{tabular}{llll}
\hline Sample ID & Ye'elimite/g & Gypsum/g & Water/g \\
\hline Series y & 3.50 & - & 3.72 \\
Series yg & 2.56 & 3.31 & 7.52 \\
Series y $1 / 2 \mathrm{~g}$ & 4.23 & 1.64 & 3.76 \\
\hline
\end{tabular}

Gypsum was supplied by Saint-Gobain (E516)

Chebyshev function and automatic background fitting. High Score Plus was chosen for the hydrated ye'elimite samples because of the high concentrations of amorphous content: the program allows for more freedom than GSAS when manual fitting of the background is required. The amorphous content in the samples was calculated with the G-factor method [40, 55-57] using an external standard (NIST, SRM-676a) [58].

TG analysis (Stanton Redcroft, STA-780) was used to determine the chemically bound water and quantify the amorphous content in hydrated ye'elimite samples. The instrument was operated from 25 to $1000{ }^{\circ} \mathrm{C}$ for hydrated samples kept at $25{ }^{\circ} \mathrm{C}$ and from 25 to $600{ }^{\circ} \mathrm{C}$ for samples previously heated sequentially at 170,200 or $230^{\circ} \mathrm{C}$ for $20 \mathrm{~min}$. The TG used a $10{ }^{\circ} \mathrm{C} \mathrm{min}^{-1}$ heating rate under continuous purging with nitrogen. The same procedure was followed for ternesite samples kept at $25{ }^{\circ} \mathrm{C}$ only. For both compounds, bound water was determined from the mass loss between 30 and $600{ }^{\circ} \mathrm{C}$.

Where the amorphous content was not successfully determined by means of Rietveld analysis, pre-treatment heat was applied before the TG analysis. Hydrated ye'elimite samples were heated isothermally for $20 \mathrm{~min}$ at 170,200 and $230{ }^{\circ} \mathrm{C}$ to remove bound water from $\mathrm{AFt}$, AFm and gypsum but not from aluminium hydroxide. Then the decomposition temperature and mass loss from aluminium hydroxide could be determined, largely free from interferences. Decomposition temperatures and consequent quantifications were calculated using the tangential method [59]. The maximum temperature chosen, $230{ }^{\circ} \mathrm{C}$, is the temperature at which aluminium hydroxide is reported to start decomposing [59]. A mercury thermometer was placed inside the box furnace to monitor the temperature with higher precision.

XRD patterns were also collected for the heat-treated ye'elimite samples on a PANanalytical X-pert diffractometer to verify that the crystalline and partly crystalline phases had fully decomposed. The instrument conditions matched exactly that of the Empyrean described earlier, with the exception that the X-pert was not fitted with a monochromator; step size was $0.0262^{\circ}$ and time per step was $30.6 \mathrm{~s}$.

\section{Materials}

\section{Ye'elimite}

Ye'elimite was synthesised by mixing stoichiometric amounts of aluminium oxide (1344-28-1, Sigma-Aldrich), calcium carbonate (471-34-1, Sigma-Aldrich) and calcium sulphate (7778-18-9, Fisher Scientific), to obtain $\mathrm{a} \approx 100$ $\mathrm{g}$ batch. The reagents were hand-mixed for $5 \mathrm{~min}$ using a mortar and a pestle, adding a few drops of ethanol to facilitate mixing. The reactants were dried at $100{ }^{\circ} \mathrm{C}$ for $2 \mathrm{~h}$, placed in a platinum crucible and heated in air in an electric furnace at $1250{ }^{\circ} \mathrm{C}$ for $20 \mathrm{~min}$. The sample was again homogenised with a mortar and a pestle for about 2 min and re-heated. After five cycles, the sample purity was 97.5 mass\% ye'elimite (85.7 mass\% orthorhombic and 11.8 mass\% cubic) as determined by XRD-Rietveld; the remaining 2.5 mass $\%$ was calcium aluminate $\left(\mathrm{CaAl}_{2} \mathrm{O}_{4}\right)$.

Ye'elimite was then divided into three portions (y, yg, $y^{1 / 2 g}$ ). The first two portions ( $y$ and $y g$ ) were blended according to Eqs. 1 and 2, without and with gypsum, respectively, while mix $\left(\mathrm{y}^{1 / 2} \mathrm{~g}\right)$ was weighted according to Eq. 2 with the only difference being that half the theoretical amount of gypsum needed to satisfy Eq. 2 was used. These three formulations were chosen to calculate the enthalpy of formation of ye'elimite: the corresponding gypsum/ye'elimite ratios were $0(\mathrm{y}), 1.02\left(\mathrm{y}^{1} / 2 \mathrm{~g}\right)$ and 2.04 $(\mathrm{yg})$. All samples were ground to a Blaine fineness of $\approx 1000 \mathrm{~m}^{2} \mathrm{~kg}^{-1}$ in order to enhance reactivity with 
water. A Retsch PM100 ball mill was used for grinding, operating at $350 \mathrm{rpm}$ for $3 \mathrm{~min}$ using $50 \mathrm{~g}$ batches.

\section{Ternesite}

Ternesite was synthesised by mixing stoichiometric amounts of previously synthesised belite with anhydrite (7778-18-9, Fisher Scientific), to obtain a 100-g batch. The belite had been synthesised by mixing stoichiometric amounts of $\mathrm{SiO}_{2}$ (14808-60-7, Fluka) and $\mathrm{CaCO}_{3}$ (471-341, Sigma-Aldrich). Reagents were then mixed and treated as for ye'elimite (see 0). Heating for a total of 3 days, at $1300{ }^{\circ} \mathrm{C}$ with 3 intermediate mixings, yielded a 100 mass $\% \mathrm{C}_{2} \mathrm{~S}$ (63.1 mass $\% \gamma$ and 36.9 mass $\% \quad \beta$ ). For the synthesis of ternesite, different combinations of dopants were also made, and an optimum (regarding hydration) was found by adding 0.2 mass $\% \mathrm{~K}_{2} \mathrm{O}, 0.1$ mass $\%$ $\mathrm{Na}_{2} \mathrm{O}$ and 0.4 mass $\% \mathrm{MgO}$ (mass\% of the total sample) [60]. The batch was sintered in a platinum crucible for $24 \mathrm{~h}$ at $1175^{\circ} \mathrm{C}$. The purity of the sample was 91.1 mass $\%$ ternesite, 5.3 mass $\%$ beta belite, 3.2 mass $\%$ gamma belite and 0.5 mass $\%$ calcium sulphate. It is possible to reach higher ternesite purity, as reported by Hanein et al. [15], but the process is slower and requires a different setup limiting synthesis to smaller quantities, maximum $20 \mathrm{~g} / \mathrm{batch}$. The purity obtained for the present study was considered sufficient for measurements; calculations are described subsequently. Ternesite was ground in 50-g batches using a Retsch ball mill, operating at $500 \mathrm{rpm}$ for $10 \mathrm{~min}$, achieving a Blaine $\approx 800 \mathrm{~m}^{2} \mathrm{~kg}^{-1}$. The ground material was then separated into three samples: $t 1, t 2$ and $t 3$ (called $t$-series).

\section{Calculations and enthalpy of formation data}

\section{Ye'elimite}

The enthalpy of formation of ye'elimite was calculated from the heat evolved during hydration and the heat of formation of the phases involved. The calculations proceed as follows:

The first step is to redefine Eqs. 1 and 2 in mass\% because the results obtained from Rietveld analysis (Gfactor method) and TG are also in mass \%; Eqs. 3 and 4 show the conversion.

$$
\begin{aligned}
& 65 \text { mass } \% \mathrm{C}_{4} \mathrm{~A}_{3} \overline{\mathrm{S}}+35 \text { mass } \% \mathrm{H} \\
& \rightarrow 67 \text { mass } \% \mathrm{AFm}+33 \text { mass } \% \mathrm{AH}_{3} \\
& 39 \text { mass } \% \mathrm{C}_{4} \mathrm{~A}_{3} \overline{\mathrm{S}}+22 \text { mass } \% \mathrm{CS} \mathrm{H}_{2}+39 \text { mass } \% \mathrm{H} \\
& \rightarrow 80 \text { mass } \% \mathrm{AFt}+20 \text { mass } \% \mathrm{AH}_{3}
\end{aligned}
$$

The heat measured in the isothermal conduction calorimeter during hydration at $25{ }^{\circ} \mathrm{C}$ equals the enthalpy of reaction; therefore, the enthalpy of formation of ye'elimite can be calculated as follows:

$\Delta_{\mathrm{r}} H^{\mathrm{o}}=\Sigma_{\mathrm{vb}} H_{\mathrm{fvb}}^{\mathrm{o}}-\Sigma_{\mathrm{va}} H_{\mathrm{fva}}^{\mathrm{o}}$,

where $H_{\mathrm{f}}^{\mathrm{o}}$ is the standard enthalpy of formation and the subscripts $b$ and $a$ stand for products and reactants, respectively. The subscripts $f$ and $r$ are used to establish the difference between the heat of formation $f$ and the heat of reaction $r$. Rearranging Eq. 5, and combining it with Eqs. 3 and 4, two equations are obtained for the enthalpy of formation of ye'elimite: Eqs. 6 and 7. Where $a, b, c, e, f, g$ and $h$ correspond to the mass $\%$ of each component as quantified using the Rietveld analysis (G-factor) and TG; $d$ and $i$ correspond to the mass $\%$ of the initial amount of ye' elimite minus the unreacted fraction, as quantified via Rietveld analysis (G-factor).

$$
\begin{aligned}
\Delta_{\mathrm{f}} \mathrm{H}_{\mathrm{C}_{4} \mathrm{~A}_{3} \overline{\mathrm{S}}}^{\mathrm{o}} & =\frac{\Delta_{\mathrm{r}} \mathrm{H}_{\text {calorimeter }}+\mathrm{aH}_{\mathrm{AFm}}^{\mathrm{o}}+\mathrm{bH}_{\mathrm{AH}_{3}}^{\mathrm{o}}-\mathrm{cH}_{\mathrm{H}}^{\mathrm{o}}}{\mathrm{d}_{\mathrm{C}_{4} \mathrm{~A}_{3} \overline{\mathrm{S}}}} \\
\Delta_{\mathrm{f}} \mathrm{H}_{\mathrm{C}_{4} \mathrm{~A}_{3} \overline{\mathrm{S}}}^{\mathrm{o}} & =\frac{\Delta_{\mathrm{r}} \mathrm{H}_{\text {calorimeter }}+e \mathrm{H}_{\mathrm{AFt}}^{\mathrm{o}}+f \mathrm{H}_{\mathrm{AH}_{3}}^{\mathrm{o}}-g \mathrm{H}_{\mathrm{H}}^{\mathrm{o}}-h \mathrm{H}_{\mathrm{CSH}_{2}}^{\mathrm{o}}}{i_{\mathrm{C}_{4} \mathrm{~A}_{3} \overline{\mathrm{s}}}}
\end{aligned}
$$

\section{Ternesite}

Hydration equations for ternesite are absent from the literature; thus, we derive Eq. 8 based on experimental observations of the reaction: ternesite plus water.

$$
\begin{aligned}
3 \mathrm{Ca}_{5}\left(\mathrm{SiO}_{4}\right)_{2} \mathrm{SO}_{4}+2 \mathrm{H}_{2} \mathrm{O} \rightarrow & \mathrm{Ca}_{9} \mathrm{Si}_{6} \mathrm{O}_{18}(\mathrm{OH})_{6} \cdot 8 \mathrm{H}_{2} \mathrm{O} \\
& +3 \mathrm{CaSO}_{4} \cdot 2 \mathrm{H}_{2} \mathrm{O} \\
& +3 \mathrm{Ca}(\mathrm{OH})_{2}
\end{aligned}
$$

A procedure similar to that used for ye'elimite was followed for ternesite. Conversion of Eq. 8 into mass units gives Eq. 9.

$$
\begin{aligned}
& 80 \text { mass } \% \mathrm{C}_{5} \mathrm{~S}_{2} \overline{\mathrm{S}}+20 \text { mass } \% \mathrm{H} \\
& \rightarrow 59 \text { mass } \% \mathrm{C}-\mathrm{S}-\mathrm{H}+29 \text { mass } \% \mathrm{C}_{\bar{S}} \mathrm{H}_{2} \\
& \quad+12 \text { mass } \% \mathrm{CH}
\end{aligned}
$$

As before; rearranging Eq. 5 and combining it with Eq. 9 gives Eq. 10.

$$
\Delta_{\mathrm{f}} \mathrm{H}_{\mathrm{C}_{5} \mathrm{~S}_{2} \overline{\mathrm{S}}}^{\mathrm{o}}=\frac{\Delta_{\mathrm{r}} \mathrm{H}_{\text {calorimeter }}+j \mathrm{H}_{\mathrm{C}-\mathrm{S}-\mathrm{H}}^{\mathrm{o}}+k \mathrm{H}_{\mathrm{CS}_{\bar{H}}}^{o}+l \mathrm{H}_{\mathrm{CH}}^{\mathrm{o}}-m \mathrm{H}_{\mathrm{H}}^{\mathrm{o}}}{n_{\mathrm{C}_{5} \mathrm{~S}_{2} \overline{\mathrm{S}}}}
$$

where $j, k, l$, and $m$ correspond to the mass $\%$ of each component as quantified by Rietveld analysis (G-factor) and TG; $n$ corresponds to the mass $\%$ of the initial amount of ternesite minus the unreacted mass, as quantified by Rietveld analysis (G-factor). 


\section{Enthalpy of formation data}

The enthalpies of formation of the relevant compounds involved in the hydration reactions for ye'elimite and ternesite are given in Table 3. Following the procedure used by Wagman et al. [12], we collected enthalpy data determined using a practical approach and where this was not possible, data were collected from theoretical approaches. Values were adopted were no significant variations were found between at least 3 studies. However, an exception was made for $\mathrm{C}-\mathrm{S}-\mathrm{H}$ data because of different definitions of " $\mathrm{C}-\mathrm{S}-\mathrm{H}$ " in the literature, with a broad range of results. For the presentment study, $\mathrm{C}-\mathrm{S}-\mathrm{H}$ data were chosen after a "trial and error" approach using $\mathrm{C}-\mathrm{S}-\mathrm{H}$ data from Ref. [61]. When the error between the generic result of the enthalpy of formation of ternesite (see section "Ye'elimite") and the experimental result was below 5\%, then $\mathrm{C}-\mathrm{S}-$ $\mathrm{H}$ enthalpy data were assumed acceptable. It was found that the most appropriate enthalpy value belonged to jennite (see Table 3); therefore, its value was used throughout all calculations for the determination of the enthalpy of formation of ternesite.

\section{Results and discussion}

\section{Ye'elimite}

The heat evolution curves for the 3 series ( $y, y g$ and $y^{1} / 2 g$ ) of ye'elimite are shown in Fig. 1. The mechanisms of reaction appear to change with composition. With no added gypsum (y), ye'elimite apparently hydrates in a single process giving an induction period followed by a nearclassical acceleration (spontaneous) until deceleration as reactants approach exhaustion. When $\mathrm{AFt}$ and both $\mathrm{AFt}$ and AFm form ( $y g$ and $y^{1 / 2 g}$ ), the induction period shortens, and the reaction occurs in incompletely resolved steps. Hydration without added gypsum (y) takes approximately $8 \mathrm{~h}$ for completion, while with gypsum, yg and $y^{1 / 2 g}$, the reaction is slower, requiring approximately 12 and $16 \mathrm{~h}$, respectively. The total heat released after $72 \mathrm{~h}$ of hydration is shown in Table 4. The repeatability of measurements, with an error below 3\%, is considered acceptable, as described in section "Methods".

Results obtained from Rietveld analysis (G-factor) for hydrated ye'elimite samples are shown in Table 5. As expected, the highest amount of ettringite was observed for the sample with a stoichiometric amount of gypsum (yg). The highest ACn (Amorphous and Crystalline not-quantified [40]) was observed for the samples without gypsum (y): this $\mathrm{ACn}$ content is attributed to both, $\mathrm{AH}_{3}$ and amorphous AFm. The amount of ACn is also significant $(\sim 50$ mass $\%)$ for the two-series containing gypsum (yg
Table 3 Enthalpy of formation at $25^{\circ} \mathrm{C}$ and the formula mass of all components involved in the calculations

\begin{tabular}{|c|c|c|c|}
\hline Components & Formula & $\begin{array}{l}\Delta_{\mathrm{f}} \mathrm{H}^{\mathrm{o}}, \\
\text { enthalpy of } \\
\text { formation/ } \\
\mathrm{J} \mathrm{g}^{-1}\end{array}$ & $\begin{array}{l}\text { Molar } \\
\text { mass/ } \\
\mathrm{g} \mathrm{mol}^{-1}\end{array}$ \\
\hline Ettringite $^{\mathrm{b}}$ & $6 \mathrm{CaO} \cdot \mathrm{Al}_{2} \mathrm{O}_{3} \cdot 3 \mathrm{SO}_{3} \cdot 32 \mathrm{H}_{2} \mathrm{O}$ & $-13,974.2$ & 1255.10 \\
\hline Kuzelite $^{\mathrm{b}}$ & $4 \mathrm{CaO} \cdot \mathrm{Al}_{2} \mathrm{O}_{3} \cdot \mathrm{SO}_{3} \cdot 12 \mathrm{H}_{2} \mathrm{O}$ & $-14,100.8$ & 622.52 \\
\hline Ye'elimite & $\mathrm{Ca}_{4} \mathrm{Al}_{6} \mathrm{O}_{12}\left(\mathrm{SO}_{4}\right)$ & - & 610.26 \\
\hline Water $^{\mathrm{a}}$ & $\mathrm{H}_{2} \mathrm{O}$ & $-15,871.3$ & 18.02 \\
\hline $\begin{array}{l}\text { Amorphous } \\
\text { aluminium } \\
\text { hydroxide }^{\text {b }}\end{array}$ & $\mathrm{Al}(\mathrm{OH})_{3}$ & $-16,359.0$ & 78.00 \\
\hline Gypsum $^{\mathrm{b}}$ & $\mathrm{CaSO}_{4} \cdot 2 \mathrm{H}_{2} \mathrm{O}$ & $-11,747.9$ & 172.17 \\
\hline $\begin{array}{l}\text { Calcium } \\
\text { aluminate }^{\mathrm{b}}\end{array}$ & $\mathrm{CaAl}_{2} \mathrm{O}_{4}$ & $-14,719.8$ & 158.04 \\
\hline Jennite $^{c}$ & $\mathrm{Ca}_{9} \mathrm{Si}_{6} \mathrm{O}_{18}(\mathrm{OH})_{6} \cdot 8 \mathrm{H}_{2} \mathrm{O}$ & $-14,283.9$ & 1063.37 \\
\hline Portlandite ${ }^{\mathrm{b}}$ & $\mathrm{Ca}(\mathrm{OH})_{2}$ & $-13,308.5$ & 74.09 \\
\hline$\beta$-belite ${ }^{b}$ & $\mathrm{Ca}_{2} \mathrm{SiO}_{4}$ & $-13,396.7$ & 172.24 \\
\hline$\gamma$-belite ${ }^{\mathrm{b}}$ & $\mathrm{Ca}_{2} \mathrm{SiO}_{4}$ & $-13,457.1$ & 172.24 \\
\hline Anhydrite $^{\mathrm{a}}$ & $\mathrm{CaSO}_{4}$ & -9711.5 & 136.14 \\
\hline Ternesite & $\mathrm{Ca}_{5}\left(\mathrm{SiO}_{4}\right)_{2} \mathrm{SO}_{4}$ & - & 480.62 \\
\hline
\end{tabular}

${ }^{\mathrm{a}}$ Data from [62], ${ }^{\mathrm{b}}$ data from [12], ${ }^{\mathrm{c}}$ data from [61]

and $y^{1} / 2 g$ ). The lower ye'elimite reactivity (degree of hydration) was observed for samples having the least water $\left(y^{1 / 2 g}\right)$. The availability of gypsum and water is the two key components that determined the speciation of hydrates when ye'elimite is hydrated [high ettringite formation $\left(\mathrm{yg}-\mathrm{y}^{1 / 2 \mathrm{~g}}\right.$ ) and high monosulphate formation $\left.(\mathrm{y})\right]$.

Differential thermogravimetric analysis (DTG) and mass losses for the hydrated ye'elimite series are shown in Figs. 2 and 3, respectively. As can be seen in Fig. 2, in samples (yg), ettringite and aluminium hydroxide are the only products; both were identified with XRD or DTG. The hydration of ye'elimite with water (y) gives monosulphate as the major phase, along with aluminium hydroxide and a small amount of ettringite (identified only by XRD). Monosulphate and aluminium hydroxide are poorly crystalline and amorphous, respectively, making it impossible to distinguish the two phases by XRD; the same applies for DTG, where mass loss curves of the constituent phases overlap making it impossible to deconvolute mass losses from the constituent phases. A similar difficulty applies to the sample that contains ye'elimite and half the theoretical amount of gypsum for ettringite formation $\left(y^{1 / 2 g}\right)$. From the XRD analysis, a small diffuse scattering feature can be identified around $10.6^{\circ} 2 \theta$, attributed to the presence of poorly crystalline monosulphate (AFm). The quantification of this small amount of monosulphate was not feasible either by Rietveld or DTG analysis. Rietveld analysis and 
Fig. 1 Heat evolution curves of ye'elimite: a without gypsum (y), b with gypsum (yg) and c with half the theoretical amount of gypsum $\left(\mathrm{y}^{1 / 2 \mathrm{~g}}\right)$ for the first $24 \mathrm{~h}$ of hydration at $25^{\circ} \mathrm{C}$. Each test was repeated 3 times, hence the notations $1,2,3$

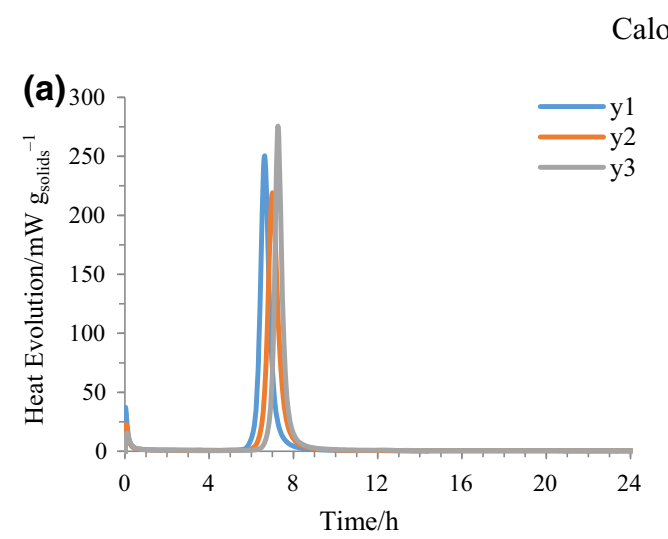

Calorimetry
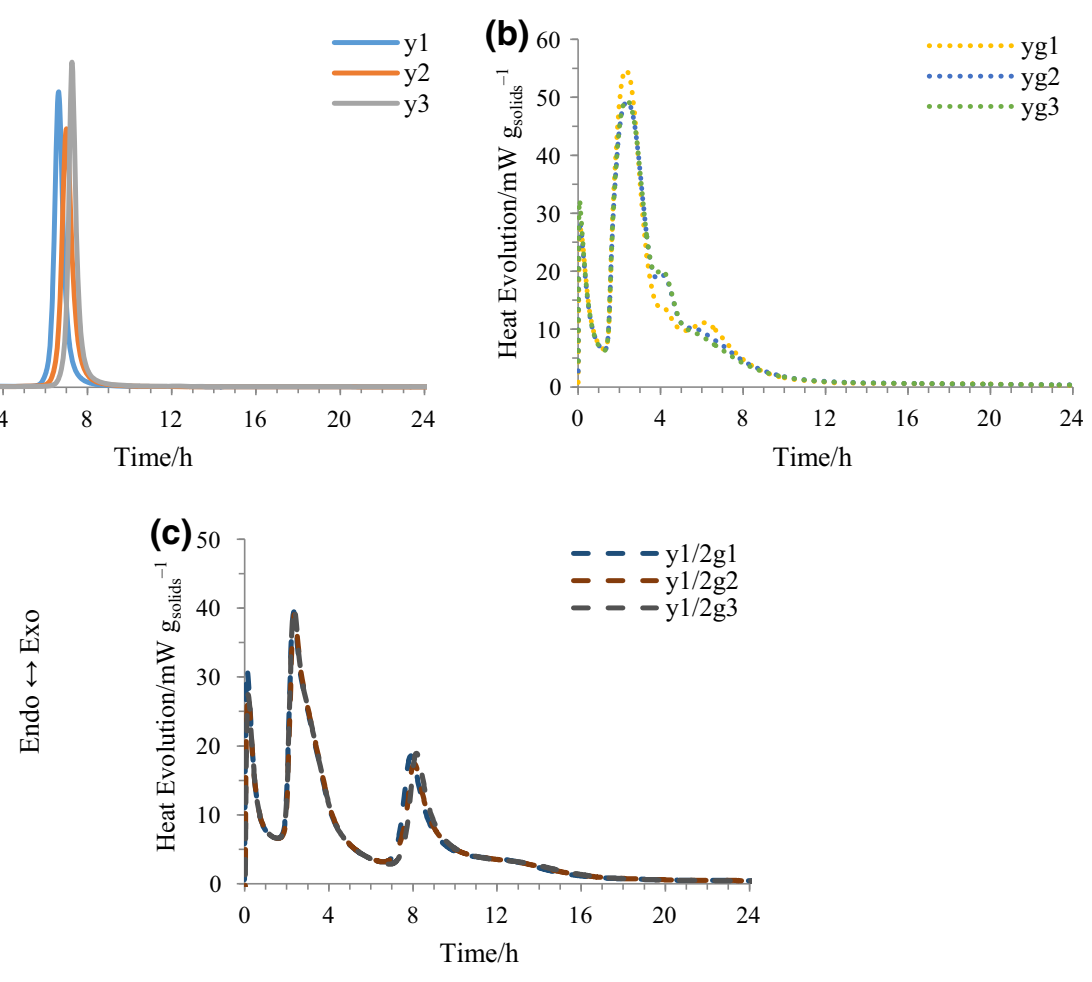

To overcome the phase identification difficulty, samples

Table 4 Total heat release of ye'elimite samples the first $72 \mathrm{~h}$ of hydration at $25^{\circ} \mathrm{C}$

\begin{tabular}{llll}
\hline Sample & Total heat/J gsample & $\mathrm{SD} / \mathrm{J} \mathrm{g}_{\text {sample }}^{-1}$ & $\begin{array}{l}\text { Error between } \\
\text { measurements/\% }\end{array}$ \\
\hline $\mathrm{y} 1$ & -303 & \\
$\mathrm{y} 2$ & -300 & & \\
$\mathrm{y} 3$ & -302 & 1.5 & 0.5 \\
Average & -302 & & \\
yg1 & -262 & & \\
yg2 & -271 & & \\
yg3 & -264 & 4.7 & \\
Average & -266 & & \\
$\mathrm{y}^{1 / 2 \mathrm{~g} 1}$ & -334 & & \\
$\mathrm{y} 1 / 2 \mathrm{~g} 2$ & -330 & & 1.5 \\
$\mathrm{y}^{1 / 2 \mathrm{~g} 3}$ & -324 & & \\
Average & -329 & 5.0 & \\
\hline
\end{tabular}

$\mathrm{SD}$ and error between the measurements are also given

the G-factor method allow for calculation of the total amount of amorphous content but not the speciation of the poorly crystalline solids. Using TG, events arising from monosulphate and ettringite overlap those arising from aluminium hydroxide decomposition. were heat-treated isothermally as described earlier to decompose selectively hydrates other than aluminium hydroxide. As shown in Figs. 4 and 5, the most appropriate treatment is to heat the samples at $200{ }^{\circ} \mathrm{C}$ for $20 \mathrm{~min}$ : at $230{ }^{\circ} \mathrm{C}$ some aluminium hydroxide decomposes, and at $170{ }^{\circ} \mathrm{C}$ monosulphate is still present. However, at $200{ }^{\circ} \mathrm{C}$, two small humps left and right of the main peak (Fig. 4) might be due to small amounts of monosulphate but, in general, represents the optimum. Once AFm and AFt are decomposed, the TG mass loss at $220-320^{\circ} \mathrm{C}$ can be attributed to aluminium hydroxide.

The extent of solid solution between the $\mathrm{OH}^{-}$and $\mathrm{SO}_{4}{ }^{2-}$-AFm phases, and hence the AFm composition, are not clear in the literature. Several authors reported complete solid solution [63-66], others partial solid solution [67-70] and others no solid solution in aged samples [71]. In the presented study, the AFm formed was a sulphateAFm from XRD evidence (kuzelite). This assignment of composition is consistent with the absence of alkali and the high sulphate environment which tends to displace $\mathrm{OH}^{-}$ from anion positions in AFm.

Qualitative XRD analysis of the heat-treated samples is in good agreement with TG, showing mainly aluminium hydroxide as the only hydration product left. In the samples treated at $200{ }^{\circ} \mathrm{C}$, AFt and gypsum (yg and $\mathrm{y}^{1} / 2 \mathrm{~g}$ ) decomposed completely, and in y samples, most of the AFm also 
Table 5 Degree of hydration of ye'elimite and gypsum and the formed hydrates normalised to $100 \mathrm{~g}$ of dried sample after $72 \mathrm{~h}$ of hydration at $25{ }^{\circ} \mathrm{C}$, determined by Rietveld analysis and the G-factor method

\begin{tabular}{|c|c|c|c|c|c|c|c|c|c|}
\hline Sample & $\mathrm{y} 1$ & $\mathrm{y} 2$ & $\mathrm{y} 3$ & yg1 & yg2 & yg3 & $\mathrm{y}^{1} / 2 \mathrm{~g} 1$ & $\mathrm{y}^{1 / 2} \mathrm{~g} 2$ & $\mathrm{y}^{1} / 2 \mathrm{~g} 3$ \\
\hline \multicolumn{10}{|c|}{ Hydrates (g $\left.100 \mathrm{~g}_{\text {dried sample }}^{-1}\right)$} \\
\hline Ettringite & 3.3 & 2.9 & 3.0 & 49.4 & 47.7 & 48.1 & 38.6 & 38.6 & 38.4 \\
\hline Monosulphate & 17.0 & 12.7 & 13.6 & 0.0 & 0.0 & 0.0 & 0.0 & 0.0 & 0.0 \\
\hline $\mathrm{ACn}$ & 75.2 & 78.7 & 78.1 & 49.9 & 51.9 & 51.4 & 50.0 & 49.4 & 50.8 \\
\hline \multicolumn{10}{|c|}{ Degree of hydration (mass $\%$ consumed) } \\
\hline $\mathrm{C}_{4} \mathrm{~A}_{3} \overline{\mathrm{S}}$-sum & 93.0 & 91.3 & 91.9 & 98.1 & 98.9 & 98.6 & 80.5 & 80.8 & 80.1 \\
\hline $\mathrm{CS} \mathrm{H}_{2}$ & N/A & N/A & N/A & 100 & 100 & 100 & 86.2 & 81.1 & 92.1 \\
\hline
\end{tabular}

ACn stands for Amorphous and Crystalline not-quantified [40]

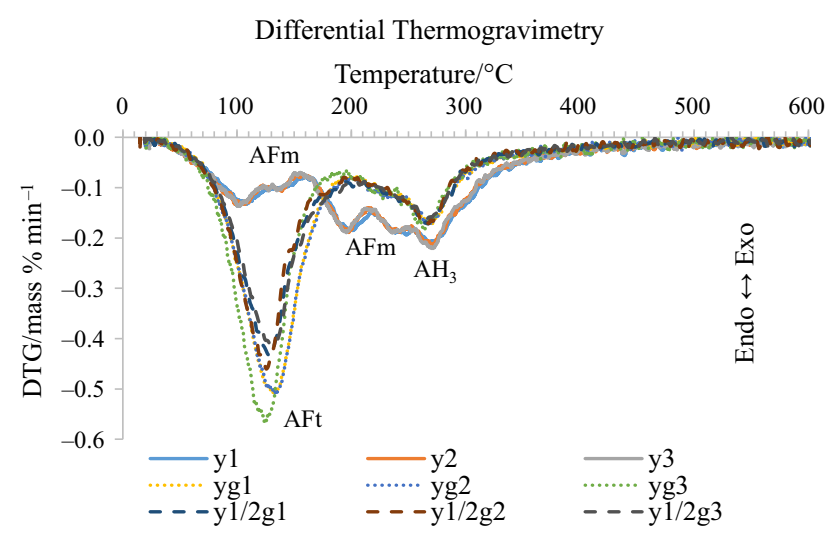

Fig. 2 Differential thermogravimetric analysis of the hydrated samples of ye'elimite with and without gypsum at $25{ }^{\circ} \mathrm{C}$

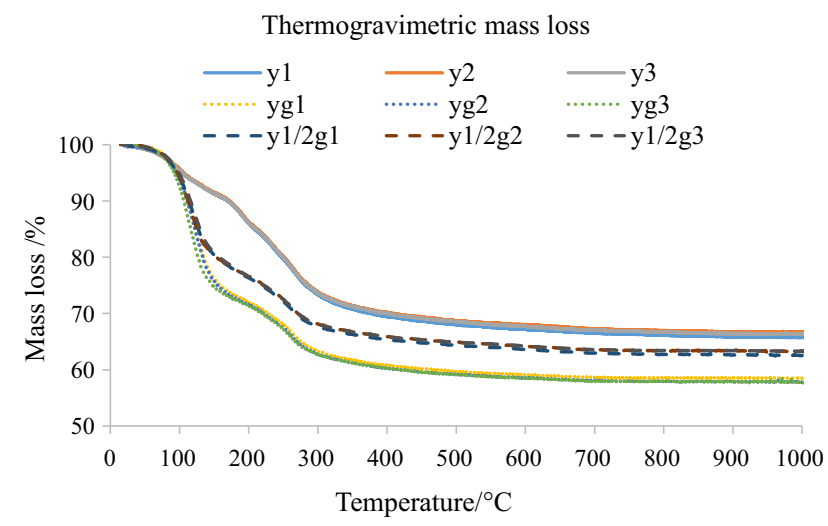

Fig. 3 Mass loss of the hydrated samples of ye'elimite with and without gypsum at $25{ }^{\circ} \mathrm{C}$

decomposed. An example of a qualitative XRD scan is shown in Fig. 6. As noted, monosulphate did not decompose completely in y samples, even after the sample was heated for $20 \mathrm{~min}$ at $230^{\circ} \mathrm{C}$, although a shift of the AFm basal spacing from around $10^{\circ}-14.5^{\circ} 2 \theta$ indicates loss of water molecules $[72,73]$.

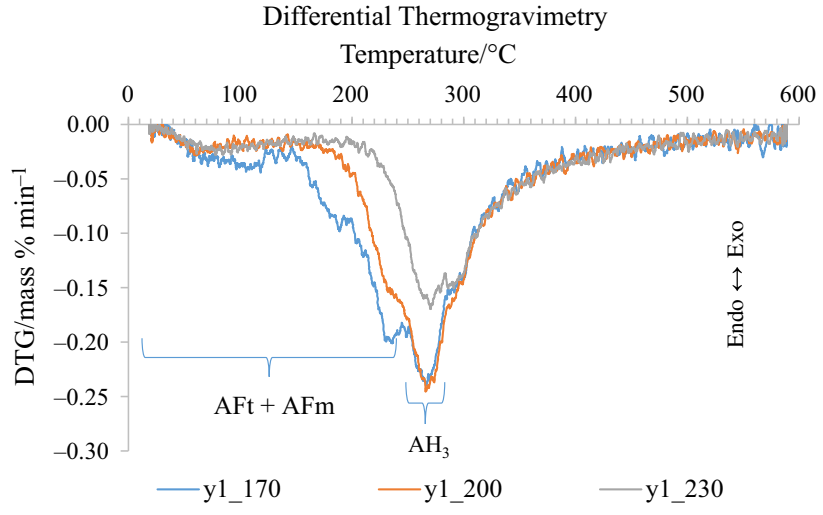

Fig. 4 Differential thermogravimetric analysis of the aluminium hydroxide peak following 20-min isothermal treatment at different temperatures 170,200 and $230{ }^{\circ} \mathrm{C}$, for a sample containing only ye'elimite and water $(\mathrm{y})$

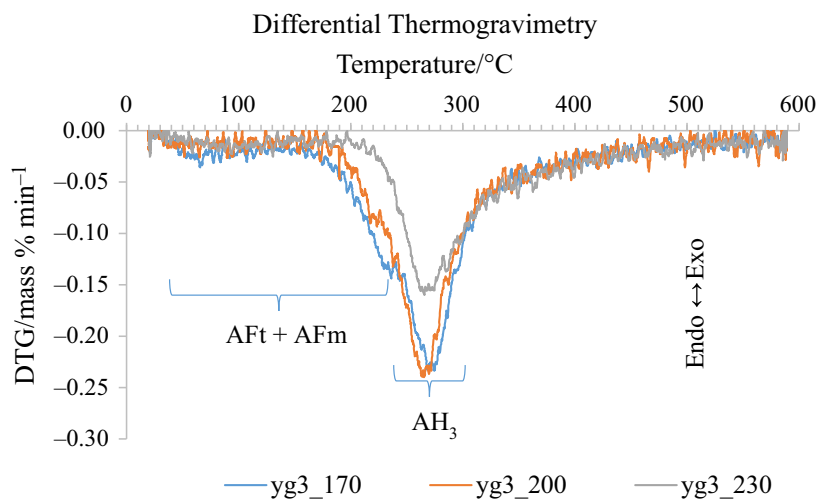

Fig. 5 Differential thermogravimetric analysis of the aluminium hydroxide peak following 20 -min isothermal treatment at different temperatures 170,200 and $230{ }^{\circ} \mathrm{C}$, for a sample containing ye'elimite, gypsum and water (yg)

Aluminium hydroxide in hydrated ye'elimite preparations decomposed between 220 and $320{ }^{\circ} \mathrm{C}$, and mass loss in that range was used for quantification. The amounts of $\mathrm{AFm}$ and/or AFt were calculated in all samples using the 


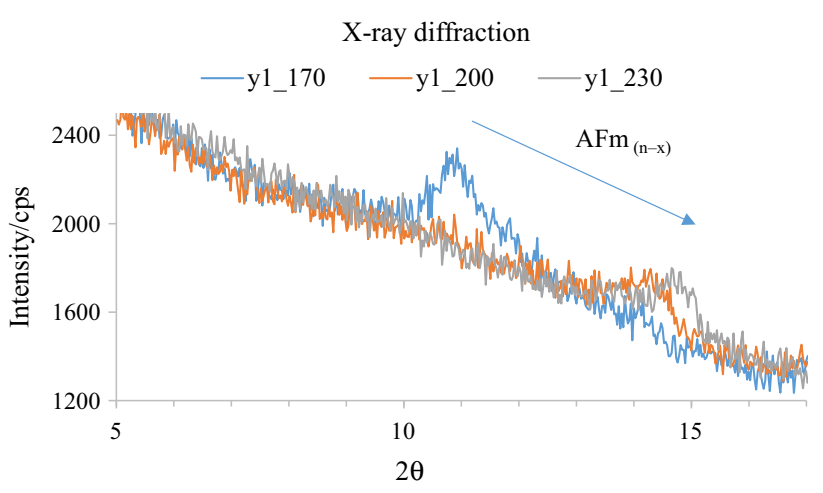

Fig. 6 AFm decomposition for sample y1 as recordered by XRD. Where $y=$ number of initial water molecules, $x=$ number of water molecules lost during heat treatment, and cps stands for counts per second

bound water loss between $30-220^{\circ} \mathrm{C}$ and between 320-600 ${ }^{\circ} \mathrm{C}$. In case of series $\mathrm{y}$, the amount of $\mathrm{AFt}$, determined by XRD (G-factor), was subtracted from the total, to calculate the amount of AFm. For series $\left(y^{1 / 2} g\right)$, the small amount of gypsum (unreacted) determined by XRD (G-factor) was also subtracted from the total in order to calculate the amount of AFt.

The deconvolution of amorphous and crystalline phases via TG improved the accuracy of the results obtained from XRD (G-factor), but as with every experimental method, inherent errors may occur. The reason we include in the quantification calculations of the loss of bound water after $320^{\circ} \mathrm{C}$ for $\mathrm{AFm}$ and $\mathrm{AFt}$ is: when comparing the quantification of the total amount of hydrates between the two methods, XRD (including the amorphous content determined via the G-factor method) and TG, results are in better agreement rather than following the bound water up to a lower temperature for AFt and AFm (until $220^{\circ} \mathrm{C}$ ). In all cases, the differences of the total amount of hydrates between the two techniques, TG and XRD, were between 0.01 and 0.7 mass\%. Our findings agree with Ref. [59]: phases in the AFm and AFt family lose water up until $600{ }^{\circ} \mathrm{C}$. Table 6 shows our best estimate of the hydration products. The main differences between Tables 5 and 6 are: a) the expression of both reactants and products as grams per $100 \mathrm{~g}$ of total sample: this includes the free water content (see caption of Table 6) and the addition of unreacted materials in "products", and b) the inclusion of $\mathrm{AH}_{3}$ and total AFm (crystalline and amorphous) in Table 6 (obtained from the heat treatment and TG measurements).

Comparing Tables 5 and 6 , it is apparent that discrepancies exist between the amounts of ettringite determined by XRD and by TG: these discrepancies are not fully resolved but relate to difficulties in fixing the boundary between a "crystalline" and an "amorphous" phase. In all cases, aluminium hydroxide was between 20 and 30 mass \%, with the highest amounts observed for sample series where gypsum was absent. The highest AFt formation was observed for sample series yg, where it is well correlated with the maximum consumption of ye'elimite and full depletion of gypsum.

With the enthalpies from Table 3, the mass $\%$ of Table 6 and the heat of reaction measured by the isothermal calorimeter (Table 4), the enthalpy of formation of ye'elimite was calculated (Table 7). Data from the three compositions (all 9 results) give high accuracy and high precision, so all 9 results are used to calculate the mean value of the enthalpy of formation of ye'elimite. The differences among the three series $\left(y, y g, y \frac{1}{2} g 1\right)$ are most likely due to quantification errors of the three main phases: AFm, AFt and $\mathrm{AH}_{3}$. The combination of two quantification techniques, XRD (Rietveld analysis and the G-factor

Table 6 Phase composition of a 100-g ye'elimite sample after $72 \mathrm{~h}$ of hydration at $25^{\circ} \mathrm{C}$, as derived from the combination of both techniques, Rietveld analysis (G-factor) at first along with the corrections based on TG

\begin{tabular}{|c|c|c|c|c|c|c|c|c|c|}
\hline Sample & $\mathrm{y} 1$ & $\mathrm{y} 2$ & y3 & yg1 & yg2 & yg3 & $\mathrm{y}^{1 / 2} \mathrm{~g} 1$ & $\mathrm{y}^{1 / 2} \mathrm{~g} 2$ & $\mathrm{y}^{1 / 2 \mathrm{~g}} 3$ \\
\hline \multicolumn{10}{|l|}{ g $100 \mathrm{~g}_{\text {paste }}^{-1}$ (reactants) } \\
\hline Ye'elimite & 47.5 & 47.5 & 47.5 & 27.4 & 27.4 & 27.4 & 46.6 & 46.6 & 46.6 \\
\hline Gypsum & N/A & N/A & N/A & 15.8 & 15.8 & 15.8 & 13.4 & 13.4 & 13.4 \\
\hline Calcium aluminate & 1.0 & 1.0 & 1.0 & 0.6 & 0.6 & 0.6 & 1.0 & 1.0 & 1.0 \\
\hline Initial water & 51.5 & 51.5 & 51.5 & 56.2 & 56.2 & 56.2 & 39.0 & 39.0 & 39.0 \\
\hline \multicolumn{10}{|l|}{$\mathrm{g} 100 \mathrm{~g}_{\text {paste }}^{-1}$ (products) } \\
\hline Ettringite & 2.8 & 2.4 & 2.5 & 64.9 & 65.8 & 66.3 & 62.2 & 61.4 & 62.8 \\
\hline Monosulphate & 48.8 & 47.9 & 48.2 & 0.0 & 0.0 & 0.0 & 0.0 & 0.0 & 0.0 \\
\hline Aluminium hydroxide & 29.0 & 28.6 & 28.7 & 21.4 & 21.3 & 20.7 & 23.6 & 23.1 & 23.0 \\
\hline Ye'elimite (unreacted) & 3.9 & 5.0 & 4.6 & 0.6 & 0.4 & 0.5 & 9.8 & 9.8 & 10.1 \\
\hline Free water & 15.5 & 16.1 & 16.0 & 13.1 & 12.6 & 12.6 & 2.4 & 2.9 & 2.9 \\
\hline Gypsum (unreacted) & N/A & N/A & N/A & 0.0 & 0.0 & 0.0 & 2.0 & 2.8 & 1.2 \\
\hline
\end{tabular}

Free water was determined by subtracting bound water taken after TG mass loss between 30 and $600{ }^{\circ} \mathrm{C}$, from the initial water 
Table 7 Enthalpy of formation of ye'elimite using 3 different mix designs $\left(\mathrm{y}, \mathrm{yg}, \mathrm{y}^{1 / 2} \mathrm{~g}\right)$ as calculated at $25^{\circ} \mathrm{C}$ along with the standard deviation (SD) and error of each experimental series and in a combination of all three

\begin{tabular}{llll}
\hline Sample & $\begin{array}{l}\Delta_{\mathrm{f}} \mathrm{H}^{\mathrm{o}}, \text { Enthalpy of } \\
\text { formation/kJ mol }\end{array}$ & $\begin{array}{l}\mathrm{SD} / \\
\mathrm{kJ} \mathrm{mol}\end{array}$ & $\begin{array}{l}\text { Error between } \\
\text { measurements/\% }\end{array}$ \\
\hline $\mathrm{y} 1$ & -8620 & & \\
$\mathrm{y} 2$ & -8624 & & \\
$\mathrm{y} 3$ & -8624 & 2 & 0.0 \\
average & -8623 & & \\
$\mathrm{yg} 1$ & -8625 & & \\
$\mathrm{yg} 2$ & -8629 & & \\
$\mathrm{yg} 3$ & -8597 & 18 & 0.2 \\
average & -8617 & & \\
$\mathrm{y}^{1} / 2 \mathrm{~g} 1$ & -8334 & & \\
$\mathrm{y}^{1} / 2 \mathrm{~g} 2$ & -8145 & & \\
$\mathrm{y}^{1 / 2 \mathrm{~g} 3}$ & -8511 & 183 & 2.2 \\
average & -8330 & 167 & 2.0 \\
total & -8523 & & \\
$\quad$ average & & & \\
\hline
\end{tabular}

The final results are converted from $\mathrm{J} \mathrm{g}^{-1}$ to $\mathrm{kJ} \mathrm{mol}^{-1}$

method) and TG, lowered the error into an acceptable range given the numerus error factors.

\section{Ternesite}

The cumulative heat data and the heat evolution curves after 72 and $24 \mathrm{~h}$ of hydration are shown in Table 8 and Fig. 7, respectively. After a small initial peak, the hydration follows a main exothermic peak with a maximum between the 3 rd and the 4th hours. Around the 5th hour, a slight shoulder is apparent, possibly indicating a new event that lasts up to $\sim 20 \mathrm{~h}$, generating low heat. Ternesite cumulative heat measurements have a slightly higher error between datasets partly because of the lower amount of heat generated per gram, compared with ye'elimite (see Tables 4, 8).

Table 8 Total heat release of the first $72 \mathrm{~h}$ of hydration of all ternesite samples at $25{ }^{\circ} \mathrm{C}$

\begin{tabular}{llll}
\hline Sample & Total heat $/ \mathrm{J} \mathrm{g}_{\text {sample }}^{-1}$ & $\mathrm{SD} / \mathrm{J} \mathrm{g}_{\text {sample }}^{-1}$ & $\begin{array}{l}\text { Error between } \\
\text { measurements } / \%\end{array}$ \\
\hline$t 1$ & -83 & & \\
$t 2$ & -87 & & \\
$t 3$ & -91 & 4.0 & 4.6 \\
Average & -87 & 4.0 & \\
\hline
\end{tabular}

Average, SD and error between the measurements are also given

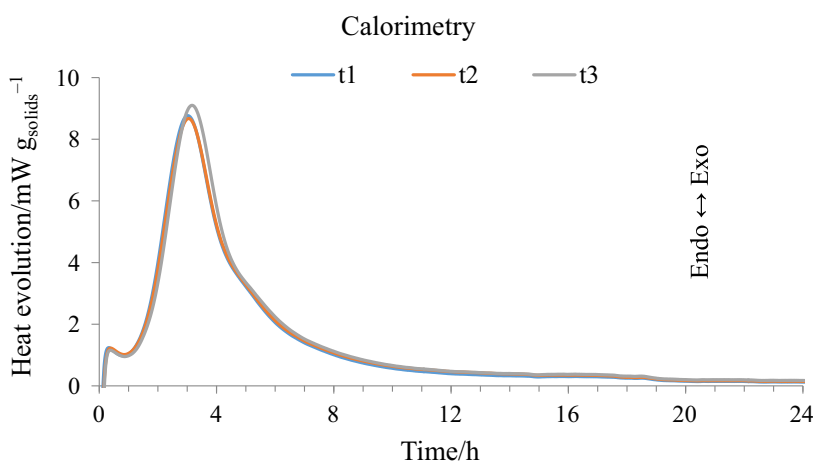

Fig. 7 Heat evolution curves of ternesite samples the first $24 \mathrm{~h}$ of hydration at $25{ }^{\circ} \mathrm{C}$

Table 9 Degree of hydration of ternesite and beta belite and the formed hydrates normalised to $100 \mathrm{~g}$ of dried sample after $72 \mathrm{~h}$ of hydration at $25^{\circ} \mathrm{C}$, as determined by Rietveld analysis and the G-factor method

\begin{tabular}{lccr}
\hline Sample & $t 1$ & $t 2$ & $t 3$ \\
\hline \multicolumn{2}{l}{ Hydrates (g 100 g dried sample) $^{-1}$ ) } & & \\
Gypsum & 8.8 & 8.5 & 8.2 \\
Portlandite & 0.4 & 0.4 & 0.4 \\
ACn & 38.0 & 39.6 & 40.5 \\
Degree of hydration (mass\% consumed) & & \\
$\mathrm{C}_{5} \mathrm{~S}_{2} \overline{\mathrm{S}}$ & 40.6 & 41.7 & 42.4 \\
$\beta-\mathrm{C}_{2} \mathrm{~S}$ & 79.6 & 78.5 & 79.6 \\
\hline
\end{tabular}

ACn stands for amorphous and crystalline not-quantified [40]

Results obtained from Rietveld analysis (G-factor method) for ternesite hydration are shown in Table 9. Ternesite shows a significant reactivity: after $72 \mathrm{~h}$, around 40 mass\% of ternesite has been consumed. Complete consumption of reactants was not achieved within $72 \mathrm{~h}$; nevertheless, Eq. 10 considers the reactivity of ternesite and, thus, will not be an obstacle for calculating the enthalpy of formation. The main hydration products are $\mathrm{C}-$ $\mathrm{S}-\mathrm{H}$ and gypsum, small amounts of portlandite are also present.

Differential thermogravimetric analysis for ternesite is shown in Fig. 8. The presence of $\mathrm{C}-\mathrm{S}-\mathrm{H}$, gypsum and portlandite is in good agreement with the XRD results; all amorphous content calculated from the G-factor method was assigned to $\mathrm{C}-\mathrm{S}-\mathrm{H}$.

The amount of $\mathrm{C}-\mathrm{S}-\mathrm{H}$ was cross-calculated via $\mathrm{TG}$ and the loss of bound water from 30 to $600{ }^{\circ} \mathrm{C}$ [59], minus the quantities of gypsum and portlandite, as determined via XRD. The composition of ternesite samples, expressed as grams per $100 \mathrm{~g}$ of total sample, are given in Table 10. The bound water (mass loss between 30 and $600{ }^{\circ} \mathrm{C}$ ) was subtracted from the initial water to calculate the free water 


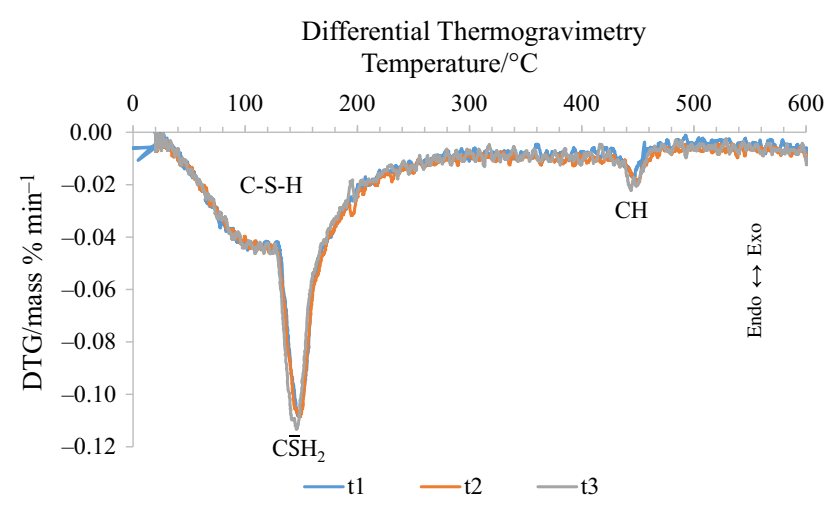

Fig. 8 Differential thermogravimetric analysis of the hydrated samples of ternesite at $25{ }^{\circ} \mathrm{C}$

Table 10 Phase composition of a $100-\mathrm{g}$ ternesite sample, as derived from the combination of both techniques, Rietveld analysis (G-factor) and TG. Free water was determined by subtracting bound water taken after TG mass loss between 30 and $600{ }^{\circ} \mathrm{C}$, from the initial water

\begin{tabular}{lrrr}
\hline Sample & \multicolumn{1}{l}{$t 1$} & \multicolumn{1}{c}{$t 3$} \\
\hline g 100 g paste (reactants) & & & \\
Ternesite & 60.72 & 60.72 & 60.72 \\
Anhydrite & 0.30 & 0.30 & 0.30 \\
$\beta$-Belite & 3.51 & 3.51 & 3.51 \\
$\gamma$-Belite & 2.13 & 2.13 & 2.13 \\
Water & 33.33 & 33.33 & 33.33 \\
g 100 gaste (products) & & & \\
C-S-H & 28.18 & 31.55 & 30.88 \\
Gypsum & 7.46 & 7.02 & 6.92 \\
$\beta$-Belite & 0.83 & 0.84 & 0.81 \\
$\gamma$-Belite & 2.67 & 2.31 & 2.38 \\
Free water & 19.02 & 18.75 & 18.83 \\
Portlandite & 0.32 & 0.35 & 0.36 \\
Ternesite & 41.52 & 39.18 & 39.81 \\
\hline
\end{tabular}

Table 11 Enthalpy of formation of ternesite as calculated at $25{ }^{\circ} \mathrm{C}$ along with the standard deviation (SD) and error

\begin{tabular}{llll}
\hline Sample & $\begin{array}{l}\Delta_{\mathrm{f}} \mathrm{H}^{\mathrm{o}}, \text { Enthalpy of } \\
\text { formation } / \mathrm{kJ} \mathrm{mol}^{-1}\end{array}$ & $\mathrm{SD} / \mathrm{kJ} \mathrm{mol}^{-1}$ & $\begin{array}{l}\text { Error between } \\
\text { measurements/\% }\end{array}$ \\
\hline$t 1$ & -5916 & & \\
$t 2$ & -6042 & & \\
$t 3$ & -6021 & 68 & 1.1 \\
Average & -5993 & 68 & \\
\hline
\end{tabular}

content needed for the calculation of the enthalpy of formation. In all three samples, the differences of the total amount of hydrates between the two techniques, TG and $\mathrm{XRD}$, were between 0.6 and 2.6 mass\%.
Table 12 Comparison of all the enthalpies of formation of ye'elimite at $25{ }^{\circ} \mathrm{C}$ with our result along with the SD and error between the presented result and the data found in the literature

\begin{tabular}{llll}
\hline & $\begin{array}{l}\Delta_{\mathrm{f}} \mathrm{H}^{\mathrm{o}}, \\
\text { Enthalpy of } \\
\text { formation/ } \\
\mathrm{kJ} \mathrm{mol}^{-1}\end{array}$ & $\begin{array}{l}\text { SD from the } \\
\text { presented } \\
\text { result/ } \\
\mathrm{kJ} \mathrm{mol}^{-1}\end{array}$ & $\begin{array}{l}\text { Error from } \\
\text { the } \\
\text { presented } \\
\text { result/\% }\end{array}$ \\
\hline $\begin{array}{l}\text { Sharp et al. [8] } \\
\text { Wenlong et al. [24] }\end{array}$ & -8413 & 78 & 0.9 \\
$\begin{array}{l}\text { Costa et al. [22] } \\
\text { Presented generic } \\
\text { result, see section } \\
\text { "Ye'elimite" (sum of } \\
\text { oxides) }\end{array}$ & -8393 & 92 & 1.1 \\
$\begin{array}{l}\text { Presented result at } \\
\text { 25 }{ }^{\circ} \mathrm{C}\end{array}$ & -8566 & 83 & 1.0 \\
\hline
\end{tabular}

${ }^{\mathrm{a} E n t h a l p y ~ d a t a ~ w e r e ~ c o l l e c t e d ~ f r o m ~ W a g m a n ~ e t ~ a l . ~[12] ~}$

Table 13 Comparison of the enthalpy of formation of ternesite at $25{ }^{\circ} \mathrm{C}$ with our result along with the SD and error between the presented result and the data found in the literature

\begin{tabular}{llll}
\hline & $\begin{array}{l}\Delta_{\mathrm{f}} \mathrm{H}^{\mathrm{o}}, \\
\text { Enthalpy of } \\
\text { formation/ } \\
\mathrm{kJ} \mathrm{mol}^{-1}\end{array}$ & $\begin{array}{l}\text { SD from the } \\
\text { presented } \\
\text { result/ } \\
\mathrm{kJ} \mathrm{mol}^{-1}\end{array}$ & $\begin{array}{l}\text { Error from } \\
\text { the } \\
\text { presented } \\
\text { result/\% }\end{array}$ \\
\hline $\begin{array}{l}\text { Presented generic } \\
\text { result, see section } \\
\text { "Ye'elimite" (sum of } \\
\text { oxides) }\end{array}$ & -5696 & 210 & 3.7 \\
$\begin{array}{l}\text { Presented result at } \\
25{ }^{\circ} \mathrm{C}\end{array}$ & -5993 & - & - \\
\hline
\end{tabular}

${ }^{\mathrm{a} E n t h a l p y ~ d a t a ~ w e r e ~ c o l l e c t e d ~ f r o m ~ W a g m a n ~ e t ~ a l . ~[12] ~}$

The main differences between Tables 9 and 10 are the inclusion of free water and the unreacted amount of ternesite in "products", as well the expression of both reactants and products as grams per $100 \mathrm{~g}$ of total sample. Consequently, the differences between the two tables in regards to the amount of $\mathrm{C}-\mathrm{S}-\mathrm{H}$ is due to the expression of the "products" as grams per $100 \mathrm{~g}$ of total sample; furthermore, $\mathrm{C}-\mathrm{S}-\mathrm{H}$ quantification values were adopted from TG. The amounts of portlandite and gypsum did not change much as both results obtained from Rietveld analysis only.

Combining enthalpies from Table 3, mass $\%$ from Table 10 and the heat of reaction from Table 8 , the enthalpy of formation of ternesite was calculated (Table 11). All three results have high accuracy and high precision, thus the inclusion of all results to calculate the mean value. 


\section{Data comparison}

The comparison of all results referenced for both phases, ye'elimite and ternesite at $25^{\circ} \mathrm{C}$, can be found in Tables 12 and 13 , respectively. Comparing the mean obtained value of the enthalpy of formation of ye'elimite, with the ones reported in references $[8,22,24]$ and with the result from the generic calculation mentioned in section "Ye'elimite", it can be seen that all 5 results are in good agreement, considering that the error around $1 \%$ is acceptable.

Unfortunately, no data exist in the literature for ternesite at $25^{\circ} \mathrm{C}$. However, comparing the generic value from section "Ye'elimite", the calculated value is in good agreement (see Table 13). The method used is validated here from the derived enthalpy of ye'elimite (see Table 11). The error from the generic value seems to be high, perhaps because: (a) the value of enthalpy of formation of the $\mathrm{C}-\mathrm{S}-\mathrm{H}^{3}$ that was inappropriate and/or (b) impurities that were present in the synthesis of ternesite might have influenced the result. Although the ternesite sample was not as phase pure as ye'elimite and the hydration degree was not as complete, the calculation was carried out successfully.

\section{Additional discussion}

The data reported here represent conditional thermodynamic values because the reaction products are not fixed or not of constant crystallinity but depend on the experimental conditions. This is for several reasons: first, the composition of a phase, e.g., C-S-H, may not be fixed: it can vary in $\mathrm{Ca} / \mathrm{Si}$ ratio as well as in water content. However, the evidence, admittedly somewhat indirect, is that the $\mathrm{C}-\mathrm{S}-\mathrm{H}$ composition is close to that of jennite. Other examples are given, for example, the ratio of hydroxide to sulphate in AFm. Secondly, the phase may vary in crystallinity: an example is aluminium hydroxide that was characterised initially as amorphous. The appellation "amorphous" was judged visually from the quality of its XRD pattern using radiation $\mathrm{Cu} \mathrm{Ka}(1.5406 \AA)$. However, although the early formed (up to $72 \mathrm{~h}$ ) product is nearly amorphous, but with time the ordering of the aluminium hydroxide phase improves, possibly towards gibbsite. As crystallinity changes, the thermodynamic properties of the solid change. Problems also arise with characterisation of the crystalline phases. We assume that the properties of solids: ternesite

\footnotetext{
${ }^{3}$ The $\mathrm{C}-\mathrm{S}-\mathrm{H}$ formation was assumed to be with a ratio of $\mathrm{Ca} / \mathrm{Si}=1.5$ to satisfy the existing data for the enthalpy of formation of $\mathrm{C}-\mathrm{S}-\mathrm{H}$ and more specifically jennite. However, the low percentages of portlandite suggests that the $\mathrm{C}-\mathrm{S}-\mathrm{H}$ formed was with a higher $\mathrm{Ca} / \mathrm{Si}$ ratio, most likely closer to 2 . Such enthalpy data unfortunately do not exist yet, hence the possible error in the measurement.
}

and ye'elimite are constant. However, ye'elimite preparations consist of variable proportions of cubic and orthorhombic variants. Probably the orthorhombic phase is a distorted, low-temperature variant of the cubic structure and the two have very similar thermodynamic properties, but the differences are not known with certainty. However, our presented result for ye'elimite is more representative for the orthorhombic polymorph.

The time- and temperature-dependent changes among the hydrate products mean that we have not determined the absolute values of equilibrium processes for some phases particularly $\mathrm{C}-\mathrm{S}-\mathrm{H}$ which persists entirely metastable. Nevertheless, what we determine is reproducible, so the data at least refer to real processes. So, while the data obtained may represent a mixture of stabilities and we are unable precisely to define the constitution of some of the constituent solids, the term "conditional" has been used to describe the values.

Cement clinkers are usually multiphase, and in some cases, the solids show strong interactions with each other as well as with water. For example, experience teaches that the hydration of ye'elimite is very sensitive to calcium sulphate content and availability and we have therefore proportioned experiments to describe different calcium sulphate/ye'elimite ratios.

Thus, several assumptions have been made to achieve the data presented here and it is impossible to give an accurate absolute estimate of the impact of errors, and moreover not all potential sources of error are evident. Nevertheless, it gives comfort that the value reported here for ye'elimite is in good agreement with others in the literature. No data have been found for ternesite at $25^{\circ} \mathrm{C}$, and the presented value is the first to be obtained.

\section{Conclusions}

The combination of isothermal conduction calorimetry, XRD and TG has proved to be a good approach for determining the enthalpy of formation of cement phases experimentally. As with any other experimental procedure, errors are present, but they can be minimised by giving close attention to methods and techniques. The presented procedure can be used to determine the enthalpy of formation of all reacting cement phases, but with care when it comes to deconvolution and identification of amorphous or poorly crystalline phases. Because the stoichiometry of the presented reactions cannot be precisely defined, the thermodynamic values in both cases, ye'elimite and ternesite, are conditional.

- After $72 \mathrm{~h}$ of hydration at $25{ }^{\circ} \mathrm{C}$, it was found that for ye'elimite: 
- At a ratio of gypsum/ye' elimite $=0, \mathrm{AFm}$ was the major phase, while AFt was also present in traces.

- At a ratio of gypsum/ye'elimite $=1.02, \mathrm{AFt}$ was the major phase, where a small percentage of AFm was also present.

- At a ratio of gypsum/ye'elimite $=2.04, \mathrm{AFt}$ was the major phase, and no AFm was observed.

- In all cases, the amount of $\mathrm{AH}_{3}$ was significant and between 20 and 30 mass\%.

- The highest consumption of ye'elimite was observed for the sample having a gypsum/ye'elimite ratio $=2.04$ and double the theoretical water according to the stoichiometric equation.

- The enthalpy of formation was calculated to be $-8523 \mathrm{~kJ} \mathrm{~mol}^{-1}$.

- After $72 \mathrm{~h}$ of hydration at $25^{\circ} \mathrm{C}$, it was found that for ternesite:

- Can hydrate with water to give mainly $\mathrm{C}-\mathrm{S}-\mathrm{H}$ and gypsum. Small percentages of portlandite were also found.

- The enthalpy of formation was calculated to be $-5993 \mathrm{~kJ} \mathrm{~mol}^{-1}$.

Acknowledgements The authors thankfully acknowledge the financial support provided by the Gulf Organisation for Research and Development (GORD) through the research Grant Number ENG016RGG11757 and the University of Aberdeen.

Open Access This article is distributed under the terms of the Creative Commons Attribution 4.0 International License (http:// creativecommons.org/licenses/by/4.0/), which permits unrestricted use, distribution, and reproduction in any medium, provided you give appropriate credit to the original author(s) and the source, provide a link to the Creative Commons license, and indicate if changes were made.

\section{References}

1. Gartner E, Quillin K. Low- $\mathrm{CO}_{2}$ cements based on calcium sulfoaluminates. Sustain Cem Concrete Ind Nor Cem Assoc. 2007;16:95-105.

2. Li G, Walenta G, Gartner E. Formation and hydration of low- $\mathrm{CO}_{2}$ cements based on belite, calcium sulfoaluminate and calcium aluminoferrite. In: 12th Int Congr Chem Cem, Montreal. 2007. p. $9-12$

3. Morin V, Walenta G, Gartner E, Termkhajornkit P, Baco I, Casabonne JM. Hydration of a belite-calcium sulfoaluminateferrite cement: Aether ${ }^{\mathrm{TM}}$. In: 13th Int Congr Chem Cem, Madrid. 2011.

4. Hanein T, Imbabi MS, Glasser FP, Bannerman MN. Lowering the carbon footprint and energy consumption of cement production: a novel Calcium SulfoAluminate cement production process. In: 1st Int Con Grand Chall Const Mater, Los Angeles. 2016.

5. WBCSD. Cement Technology Roadmap. 2009.

6. WBCSD. Low Carbon Technology Partnerships initiative. 2015.
7. Glasser FP, Zhang L. High-performance cement matrices based on calcium sulfoaluminate-belite compositions. Cem Concr Res. 2001;31:1881-6.

8. Sharp J, Lawrence C, Yang R. Calcium sulfoaluminate cements-low-energy cements, special cements or what? Adv Cem Res. 1999;11:3-13.

9. Lan W, Glasser FP. Hydration of calcium sulphoaluminate cements. Adv Cem Res. 1996;8:127-34.

10. Zhang L, Glasser FP. Hydration of calcium sulfoaluminate cement at less than $24 \mathrm{~h}$. Adv Cem Res. 2002;14:141-55.

11. Hanein T, Glasser F, Bannerman M. Thermodynamics of Portland cement clinkering. In: 14th Int Congr Chem Cem, Beijing. 2015.

12. Wagman DD, Evans WH, Parker VB, Schumm RH, Halow I. The NBS tables of chemical thermodynamic properties. Selected values for inorganic and $\mathrm{C} 1$ and $\mathrm{C} 2$ organic substances in SI units. Nat Stand Ref Data Sys. 1982.

13. Imbabi MS, Glasser FP, Galan I. Method for producing cement. US patent, Application 14/888, 183, 2014.

14. Hanein T, Galan I, Elhoweris A, Khare S, Skalamprinos S, Jen G, Whittaker M, Imbabi MS, Glasser FP, Bannerman MN. Production of belite calcium sulfoaluminate cement using sulfur as a fuel and as a source of clinker sulfur trioxide: pilot kiln trial. Adv Cem Res. 2016;28:643-53.

15. Hanein T, Galan I, Glasser FP, Skalamprinos S, Elhoweris A, Imbabi MS, Bannerman MN. Stability of ternesite and the production at scale of ternesite-based clinkers. Cem Concr Res. 2017;98:91-100.

16. Galan I, Elhoweris A, Hanein T, Bannerman MN, Glasser FP. Advances in clinkering technology of calcium sulfoaluminate cement. Adv Cem Res. 2017; doi:10.1680/jadcr.17.00028.

17. Galan I, Hanein T, Elhoweris A, Bannerman MN, Glasser FP. Phase compatibility in the system $\mathrm{CaO}-\mathrm{SiO}_{2}-\mathrm{Al}_{2} \mathrm{O}_{3}-\mathrm{SO}_{3}-\mathrm{Fe}_{2} \mathrm{O}_{3}$ and the effect of partial pressure on the phase stability. Ind Eng Chem Res. 2017;56:2341-9.

18. Kulik DA, Wagner T, Dmytrieva SV, Kosakowski G, Hingerl FF, Chudnenko KV, Berner UR. GEM-Selektor geochemical modeling package: revised algorithm and GEMS3K numerical kernel for coupled simulation codes. Comput Geosci. 2013;17:1-24.

19. Wagner T, Kulik DA, Hingerl FF, Dmytrieva SV. GEM-Selektor geochemical modeling package: TSolMod library and data interface for multicomponent phase models. Can Mineral. 2012;50:1173-95.

20. Cuesta A, Álvarez-Pinazo G, Sanfélix SG, Peral I, Aranda MAG, De la Torre AG. Hydration mechanisms of two polymorphs of synthetic ye'elimite. Cem Concr Res. 2014;63:127-36.

21. Jansen D, Spies A, Neubauer J, Ectors D, Goetz-Neunhoeffer F. Studies on the early hydration of two modifications of ye'elimite with gypsum. Cem Concr Res. 2017;91:106-16.

22. Costa U, Massazza F, Testolin M. Heats of formation of $\mathrm{C}_{4} \mathrm{~A}_{3} \overline{\mathrm{S}}$, 4SrO $3 \mathrm{Al}_{2} \mathrm{O}_{3}$. Il Cemento. 1972;2:61-8.

23. Ayed F, LeHoux P, Sorrentino F. Calcium sulfoaluminate formation. In: 14th Int Con Cem Micro. Costa Mesa. 1992. p. $325-333$.

24. Wenlong W, Xiaodong C, Ying C, Yong D, Chunyuan M. Calculation and verification for the thermodynamic data of $3 \mathrm{CaO} \cdot 3 \mathrm{Al}_{2} \mathrm{O}_{3} \cdot \mathrm{CaSO}_{4}$. Chin J Chem Eng. 2011;19:489-95.

25. Wen YK, Shao J, Wang SS, Chen DW. A simplified formula to calculate heat of formation of oxyacid salt and mineral. Acta Metall Sin. 1979;15(08):98-108.

26. Hanein T, Elhoweris A, Galan I, Glasser FP, Bannerman MC. Thermodynamic data of ye'elimite $\left(\mathrm{C}_{4} \mathrm{~A}_{3} \overline{\mathrm{S}}\right)$ for cement clinker equilibrium calculations. In: 35th Cem Concr Res. 2015.

27. Choi G, Glasser FP. The sulphur cycle in cement kilns: vapour pressures and solid-phase stability of the sulphate phases. Cem Concr Res. 1988;18:367-74. 
28. Beretka J, de Vito B, Santoro L, Sherman N, Valenti GL. Utilisation of industrial wastes and by-products for the synthesis of special cements. Resour Conserv Recycl. 1993;9:179-90. doi:10. 1016/0921-3449(93)90002-W.

29. Sherman N, Beretka J, Santoro L, Valenti GL. Long-term behaviour of hydraulic binders based on calcium sulfoaluminate and calcium sulfosilicate. Cem Concr Res. 1995;25:113-26.

30. Beretka J, Marroccoli M, Sherman N, Valenti GL. The influence of $\mathrm{C}_{4} \mathrm{~A}_{3} \overline{\mathrm{S}}$ content and WS ratio on the performance of calcium sulfoaluminate-based cements. Cem Concr Res. 1996;26:1673-81.

31. Beretka J, Cioffi R, Marroccoli M, Valenti GL. Bulk inert waste: an opportunity for use energy-saving cements obtained from chemical gypsum and other industrial wastes. Waste Manag. 1996;16:231-5. doi:10.1016/S0956-053X(96)00046-3.

32. Tadzhiev T, Atakuziev T, Tadzhiev F. Hardening of anhydrous calcium sulphoaluminate and sulfosilicate. UDC. 1973;691:1434-7.

33. Haha MB, Bullerjahn F, Zajac M. On the reactivity of ternesite. In: 14th Int Congr Chem Cem, Beijing. 2015.

34. Dienemann W, Schmitt D, Bullerjahn F, Haha MB. Belite-Calciumsulfoaluminate-Ternesite (BCT) - a new low carbon clinker technology. Cem Int. 2013;11:100-9.

35. Bullerjahn F, Schmitt D, Ben Haha M. Effect of raw mix design and of clinkering process on the formation and mineralogical composition of (ternesite) belite calcium sulphoaluminate ferrite clinker. Cem Concr Res. 2014;59:87-95.

36. Bullerjahn F, Zajac M, Ben Haha M. CSA raw mix design: effect on clinker formation and reactivity. Mater Struct. 2015;48: 3895-911.

37. Dienemann W, Haha MB. Belite Calcium sulfoaluminate Ternesite (BCT) - a new alternative binder concept. In: 19th Int Con Build Mater, Weimar. 2015.

38. Rietveld $\mathrm{H}$. A profile refinement method for nuclear and magnetic structures. J Appl Cryst. 1969;2:65-71.

39. Larson AC, Von Dreele RB. General structure analysis system (GSAS). Rep No LA-UR 86. 2004.

40. Aranda MA, Ángeles G, León-Reina L. Rietveld quantitative phase analysis of OPC clinkers, cements and hydration products. Rev Miner Geochem. 2012;74:169-209.

41. De La Torre AG, Bruque S, Aranda MA. Rietveld quantitative amorphous content analysis. J Appl Cryst. 2001;34:196-202.

42. Goetz-Neunhoeffer $F$, Neubauer J. Refined ettringite $\left(\mathrm{Ca}_{6} \mathrm{Al}_{2}(-\right.$ $\left.\left.\mathrm{SO}_{4}\right) 3(\mathrm{OH})_{12} \cdot 26 \mathrm{H}_{2} \mathrm{O}\right)$ structure for quantitative X-ray diffraction analysis. Powder Diffr. 2006;21:4-11.

43. Allmann R. Refinement of the hybrid layer structure $\left(\mathrm{Ca}_{2}\right.$ $\left.\mathrm{Al}(\mathrm{OH})_{6}\right)+\left(0.5 \quad \mathrm{SO}_{4} \cdot 3 \mathrm{H}_{2} \mathrm{O}\right) . \quad$ Monatshefte $\quad($ Band $=\mathrm{Jahr})$. 1950;136-44.

44. Calos NJ, Kennard CH, Whittaker AK, Davis RL. Structure of calcium aluminate sulfate $\mathrm{Ca}_{4} \mathrm{Al}_{6} \mathrm{O}_{16} \mathrm{~S}$. J Solid State Chem. 1995;119:1-7.

45. Saalfeld H, Depmeier W. Silicon-free compounds with sodalite structure. Cryst Res Technol. 1972;7:229-33.

46. Cole W, Lancucki C. A refinement of the crystal structure of gypsum $\mathrm{CaSO}_{4} \cdot 2 \mathrm{H}_{2} \mathrm{O}$. Acta Cryst Sect B Struct Crystallogr Cryst Chem. 1974;30:921-9.

47. Hoerkner W, Mueller Buschbaum H. Zur Kristallstruktur von $\mathrm{CaAl}_{2} \mathrm{O}_{4}$. J Inorg Nucl Chem. 1976;38:983-4.

48. Többens D, Stüßer N, Knorr K, Mayer H, Lampert G. E9: the new high-resolution neutron powder diffractometer at the Berlin neutron scattering center. Mater Sci Forum. 2001;378:288-93.

49. Irran E, Tillmanns E, Hentschel G. Ternesite, $\mathrm{Ca}_{5}\left(\mathrm{SiO}_{4}\right)_{2} \mathrm{SO}_{4}$, a new mineral from the Ettringer Bellerberg/Eifel, Germany. Miner Pet. 1997;60:121-32.

50. Chaix-Pluchery O, Pannetier J, Bouillot J, Niepce J. Structural prereactional transformations in $\mathrm{Ca}(\mathrm{OH})_{2}$. J Solid State Chem. 1987;67:225-34.
51. Mumme W, Hill R, Bushnell-Wye G, Segnit E. Rietveld crystal structure refinements, crystal chemistry and calculated powder diffraction data for the polymorphs of dicalcium silicate and related phases. Neues Jahrbuch für Mineralogie-Abhandlungen. 1995; 169:35-68.

52. Kirfel A, Will G. Charge density in anhydrite, $\mathrm{CaSO}_{4}$, from X-ray and neutron diffraction measurements. Acta Cryst Sect B Struct Crystallogr Cryst Chem. 1980;36:2881-90.

53. Wadsö L. Operational issues in isothermal calorimetry. Cem Concr Res. 2010;40:1129-37.

54. Galan I, Beltagui H, García-Maté M, Glasser F, Imbabi M. Impact of drying on pore structures in ettringite-rich cements. Cem Concr Res. 2016;84:85-94.

55. Jansen D, Stabler Ch, Goetz-Neunhoeffer F, Dittrich S, Neubauer J. Does Ordinary Portland Cement contain amorphous phase? A quantitative study using an external standard method. Powder Diffr. 2011;26:31-8.

56. Jansen D, Goetz-Neunhoeffer F, Lothenbach B, Neubauer J. The early hydration of Ordinary Portland Cement (OPC): an approach comparing measured heat $\mathrm{fl}$ ow with calculated heat flow from QXRD. Cem Concr Res. 2012;42:134-8.

57. Álvarez-Pinazo G, Cuesta A, García-Maté M, Santacruz I, Losilla ER, la Torre AGD, León-Reina L, Aranda MAG. Rietveld quantitative phase analysis of Yeelimite-containing cements. Cem Concr Res. 2012;42:960-71.

58. Cline JP, Von Dreele RB, Winburn R, Stephens PW, Filliben JJ. Addressing the amorphous content issue in quantitative phase analysis: the certification of NIST standard reference material 676a. Acta Crystallogr Sect A Found Crystallogr. 2011;67: 357-67.

59. Scrivener K, Snellings R, Lothenbach B. A practical guide to microstructural analysis of cementitious materials. CRS Press US. Taylor \& Francis Group. 2016.

60. Skalamprinos S, Jen G, Galan I, Whittaker M, Elhoweris A, Glasser F. The synthesis and hydration of ternesite, $\mathrm{Ca}_{5}\left(\mathrm{SiO}_{4}\right)_{2}$ $\mathrm{SO}_{4}$. Cem Concr Res. Unpublished manuscript/under review.

61. Blanc P, Bourbon X, Lassin A, Gaucher EC. Chemical model for cement-based materials: temperature dependence of thermodynamic functions for nanocrystalline and crystalline $\mathrm{C}-\mathrm{S}-\mathrm{H}$ phases. Cem Concr Res. 2010;40:851-66.

62. Matschei T, Lothenbach B, Glasser FP. Thermodynamic properties of Portland cement hydrates in the system $\mathrm{CaO}-\mathrm{Al}_{2} \mathrm{O}_{3}$ $\mathrm{SiO}_{2}-\mathrm{CaSO}_{4}-\mathrm{CaCO}_{3}-\mathrm{H}_{2} \mathrm{O}$. Cem Concr Res. 2007;37: 1379-410.

63. Jones F. The quaternary system $\mathrm{CaO}-\mathrm{Al} 2 \mathrm{O} 3-\mathrm{CaSO} 4-\mathrm{H} 2 \mathrm{O}$ at $25^{\circ} \mathrm{C}$. Trans Faraday Soc. 1939;35:1484-510.

64. D'Ans J, Eick H. Das System CaO-Al2O3-CaSO4-H2O bei $20{ }^{\circ} \mathrm{C}$. Zement-Kalk-Gibs. 1953;6:302-11.

65. Turriziani R, Schippa G. Riconoscimento all'ATD ed ai raggi X dei solidi quaternari $\mathrm{CaO}-\mathrm{Al}_{2} \mathrm{O}_{3}-\mathrm{CaSO}_{4}-\mathrm{H}_{2} \mathrm{O} .1955$.

66. Kalousek GL. Sulfoaluminates of calcium as stable and metastable phases, and a study of a portion of the five-component system $\mathrm{CaO}-\mathrm{SO}_{3}-\mathrm{Al}_{2} \mathrm{O}_{3}-\mathrm{Na}_{2} \mathrm{O}-\mathrm{H}_{2} \mathrm{O}$ at $25^{\circ} \mathrm{C}$. Diss. 1941.

67. Roberts $\mathrm{MH}$. Calcium aluminate hydrates and related basic salt solid solutions. In: 5th Int. Sym Chem Cem. Tokyo, vol. 2. 1969. p. 104-117.

68. Seligmann P, Greening NR. Phase equilibria of cement-water. In: 5th Int. Sym Chem Cem. Tokyo, vol. 2. 1969. p. 179-200.

69. Pollmann $\mathrm{H}$. Solid-solution in the system $3 \mathrm{CaO} \cdot \mathrm{Al}_{2} \mathrm{O}_{3} \cdot \mathrm{CaSO}_{4} \cdot \mathrm{AQ}-$ $3 \mathrm{CaO} \cdot \mathrm{Al}_{2} \mathrm{O}_{3} \cdot \mathrm{Ca}(\mathrm{OH})_{2} \cdot \mathrm{AQ}-\mathrm{H}_{2} \mathrm{O}$ at $25^{\circ} \mathrm{C}, \quad 45^{\circ} \mathrm{C}, \quad 60^{\circ} \mathrm{C}, \quad 80^{\circ} \mathrm{C}$. Neues Jahrbuch für Mineralogie-Abhandlungen. 1989;161: $27-40$.

70. Glasser F, Kindness A, Stronach S. Stability and solubility relationships in AFm phases: part I. Chloride, sulfate and hydroxide. Cem Concr Res. 1999;29:861-6. 
71. Zhang M. Incorporation of oxyanionic B, Cr, Mo, and Se into hydrocalumite and ettringite, application to cementitious systems. University of Waterloo. Diss. 2000.

72. Baquerizo LG, Matschei T, Scrivener KL, Saeidpour M, Wadsö L. Hydration states of AFm cement phases. Cem Concr Res. 2015;73:143-57.
73. Baquerizo LG, Matschei T, Scrivener KL, Saeidpour M, Thorell A, Wadsö L. Methods to determine hydration states of minerals and cement hydrates. Cem Concr Res. 2014;65:85-95. 